\title{
Genetic Manipulation of the Obligate Chemolithoautotrophic Bacterium Thiobacillus denitrificans
}

\author{
Harry R. Beller ${ }^{a}, *$, Tina C. Legler ${ }^{b}$, and Staci R. Kane ${ }^{b}$
}

a

Lawrence Berkeley National Laboratory

b Lawrence Livermore National Laboratory

* Corresponding author: HRBeller@lbl.gov

Running Head: Genetic Manipulation of Thiobacillus denitrificans 


\section{Summary}

Chemolithoautotrophic bacteria can be of industrial and environmental importance, but they present a challenge for systems biology studies, as their central metabolism deviates from that of model organisms and there is a much less extensive experimental basis for their gene annotation than for typical organoheterotrophs. For microbes with sequenced genomes but unconventional metabolism, the ability to create knockout mutations can be a powerful tool for functional genomics and thereby render an organism more amenable to systems biology approaches. In this chapter, we describe a genetic system for $T$. denitrificans, with which insertion mutations can be introduced by homologous recombination and complemented in trans. Insertion mutations are generated by in vitro transposition, the mutated genes are amplified by the PCR, and the amplicons are introduced into $T$. denitrificans by electroporation. Use of a complementation vector, pTL2, based on the IncP plasmid pRR10 is also addressed.

Key words: chemolithoautotroph; genetic system; Thiobacillus denitrificans

\section{Introduction}

Microbial systems biology relies on accurate gene annotation, which in turn relies on the presence of well-established metabolic pathways and/or experimental data on the function of gene products. While well-characterized, model microbes are amenable to systems biology approaches, bacteria with central metabolism that deviates from organoheterotrophy (such as chemolithoautotrophs) are substantially more difficult to model without experimental data tying genes to functions. For microbes with sequenced genomes but unconventional metabolism, the ability to inactivate target genes can be a powerful tool for functional genomics and thereby render an organism more amenable to systems biology approaches. In this chapter, we describe a genetic system developed for Thiobacillus denitrificans, an obligate chemolithoautotrophic bacterium that has a number of environmentally and industrially relevant metabolic activities. The genetic system, which allows one to 
create insertion mutants and complement them in trans, has already provided insights into the unusual metabolic capabilities of this bacterium.

Thiobacillus denitrificans is a widespread, obligately chemolithoautotrophic bacterium with an unusual metabolic repertoire that is perhaps best known for its ability to conserve energy from the oxidation of inorganic sulfur compounds (such as $\mathrm{H}_{2} \mathrm{~S}$ ) under either aerobic or denitrifying conditions (1). First isolated over a century ago, $T$. denitrificans has recently garnered attention for its relevance to certain industrial and environmental processes. Industrially, T. denitrificans has been used to mitigate biogenic sulfide production (souring) in oil fields by co-injection of this sulfide-oxidizing bacterium with nitrate (2). Environmentally relevant capabilities of $T$. denitrificans include in situ biodegradation of nitrate, a major groundwater contaminant worldwide, by anaerobic, nitrate-dependent oxidation of minerals such as FeS and pyrite $\left(\mathrm{FeS}_{2}\right)$ (3-5). T. denitrificans has also been used for ex situ treatment of nitrate-contaminated water, including groundwater $(6,7)$. In addition, $T$. denitrificans can catalyze anaerobic, nitrate-dependent oxidation of U(IV) oxide minerals (8), which could partially counteract efforts to remediate uranium-contaminated aquifers by in situ reductive immobilization [i.e., microbially mediated conversion of relatively soluble $\mathrm{U}(\mathrm{VI})$ species to poorly soluble $\mathrm{U}(\mathrm{IV})$ minerals], as documented in a recent field study (9).

Recent developments have made $T$. denitrificans a more favorable subject for systems biology studies, including detailed analysis of the genome (1), whole-genome transcriptional studies (10), and development of a genetic system (11). In particular, the genetic system has revealed functions for certain gene products that would have been extremely difficult to elucidate without this experimental approach. For example, targeted knockout and complementation studies demonstrated, for the first time, genes associated with anaerobic, nitrate-dependent U(IV) oxidation (12). The two genes identified, both diheme, c-type cytochromes, had originally been annotated as c-type cytochromes (1), but their role in U(IV) oxidation had (understandably) not been predicted. Another example of 
important information about $T$. denitrificans metabolism revealed by gene knockout studies concerns $\mathrm{H}_{2}$ oxidation under denitrifying conditions by [NiFe]hydrogenases. T. denitrificans has two annotated hydrogenases (1): (i) a periplasmic group 1 [NiFe]hydrogenase presumed to catalyze $\mathrm{H}_{2}$ oxidation and (ii) a cytoplasmic, heterotetrameric, group $3 \mathrm{~b}$ [NiFe]hydrogenase that is typically associated with $\mathrm{H}_{2}$ evolution as a means of disposing of excess reducing equivalents under fermentative conditions. When the large subunit of the periplasmic hydrogenase (hynL) was disrupted with an insertion mutation, there was a $75 \%$ decrease in the rate of specific hydrogen oxidation relative to the wild type (11). A doubleknockout, with a disruption in the large subunit of the cytoplasmic hydrogenase (hydA) as well as in hynL, did not result in an additional decrease in the rate of specific hydrogen oxidation (11). The residual hydrogenase activity ( $25 \%$ of wild-type activity) in the double-knockout leaves open the possibility that an additional hydrogenase is encoded in the $T$. denitrificans genome but has not yet been identified. Thus, the genetic system for $T$. denitrificans confirmed the $\mathrm{H}_{2}$-oxidizing activity of the group 1 [NiFe]hydrogenase, supported that the putative group 3b [NiFe]hydrogenase was not involved in $\mathrm{H}_{2}$ oxidation, and suggested that an additional hydrogenase may be present.

There are few chemolithoautotrophic bacteria for which genetic systems have been reported. Work with Halothiobacillus neapolitanus (formerly Thiobacillus neapolitanus) represents the earliest published example of the successful introduction of a wide-host-range plasmid into a chemolithoautotrophic bacterium (13). Later studies of $H$. neapolitanus created an insertion mutation in the $c b b L$ gene, which encodes the large subunit of Form I ribulose 1,5-bisphosphate carboxylase/oxygenase (14). Successful transfer of broad-host-range plasmids into the well-studied, biomining bacterium Acidithiobacillus ferrooxidans (formerly Thiobacillus ferrooxidans) has been reported (15), and a recA insertion mutant was created by marker exchange mutagenesis (16). Marker exchange was used on another Acidithiobacillus strain, $A$. caldus, to generate arsB and tetH mutants (17). Note that these Halothiobacillus and Acidithiobacillus strains are phylogenetically and 
physiologically distinct from $T$. denitrificans, as they belong to the $\gamma$-proteobacteria ( $T$. denitrificans belongs to the $\beta$-proteobacteria) and are strongly or moderately acidophilic ( $T$. denitrificans is neutrophilic).

In this chapter, we provide detailed methods for cultivation of $T$. denitrificans (Section 3.1) as well as generation of insertion mutants (Section 3.2) and complementation of insertion mutants (Section 3.3) in this bacterium. Cultivation methods include growth under denitrifying conditions in liquid medium as well as anaerobic growth on agar plates. Methods for mutant generation include the following: (1) isolation of T. denitrificans genomic DNA (Section 3.2.1), (2) PCR amplification of target and flanking gene sequences from $T$. denitrificans (Section 3.2.2), (3) in-vitro transposition of target genes (Section 3.2.3), (4) screening for insertional gene disruption (Section 3.2.4), (5) preparation of electrocompetent $T$. denitrificans cells (Section 3.2.5), (6) transformation of disrupted genes into $T$. denitrificans (Section 3.2.6), and (7) confirmation of properly constructed insertion mutants in $T$. denitrificans (Section 3.2.7). Complementation methods include complementation vector construction (Section 3.3.1) and confirmation of the genotype of complemented mutants in $T$. denitrificans (Sections 3.3.2 and 3.3.3). 


\section{Materials}

\subsection{Bacterial strains, plasmids, and transposons}

Bacterial strains, plasmids, and transposons needed for the described methods are listed in Table 1. A map of the complementation vector pTL2 is shown in Fig. 1.

\subsection{Reagents and Stock Solutions}

\section{$\underline{\text { 2.2.1 Materials for isolation of genomic DNA from } T \text {. denitrificans }}$}

$10 \mathrm{mM}$ Tris, $1 \mathrm{mM}$ EDTA, pH 8.0 (hereafter referred to as "TE").

$10 \%$ Sodium dodecyl sulfate

$50 \mathrm{mg} / \mathrm{mL}$ proteinase $\mathrm{K}$

$5 \mathrm{M} \mathrm{NaCl}$

$10 \%$ Cetyltrimethylammonium bromide (CTAB)/0.7 M NaCl (see Note 1)

Chloroform: Isoamyl alcohol (24:1)

Phenol:Chloroform:Isoamyl alcohol (25:24:1)

99\% Isopropanol, molecular biology grade

70\% Ethanol, molecular biology grade

$5 \mu \mathrm{g} / \mu \mathrm{L}$ RNase A

Stirring heat block

2.2.2 Materials for amplification of target genes and flanking DNA from $T$. denitrificans

PCR-grade water

Forward primer for T. denitrificans gene of interest, with Kpnl restriction site

Reverse primer for $T$. denitrificans gene of interest, with KpnI restriction site

Advantage-GC 2 Genomic PCR Kit (Clontech, Mountain View, CA)

1-10 ng/ $\mu \mathrm{L}$ T. denitrificans genomic DNA

DNA Molecular weight and mass ladder (Hi-Lo Ladder, Bionexus, Oakland, CA) 
Spin-column gel extraction kit (Qiagen, Valencia, CA, or similar)

Spin-column PCR purification kit (Qiagen or similar)

\subsubsection{Materials for in-vitro transposition of target genes}

pUC19 plasmid (Invitrogen, Carlsbad, CA)

Primers for pUC19 Multiple Cloning Site (MCS)

$$
\begin{aligned}
& \text { pUC19 - MCS forward GCCAGGGTTTTCCCAGTCACGA } \\
& \text { pUC19 - MCS reverse GAGCGGATAACAATTTCACACAGG }
\end{aligned}
$$

Kpnl restriction enzyme, 10000 units/mL (New England Biolabs, Ipswich, MA). 10X NEBuffer 1 and 10 $\mathrm{mg} / \mathrm{mL}$ Bovine Serum Albumin are included with the enzyme.

Antarctic Phosphatase, 5000 units/mL (New England Biolabs). 10X Antarctic Phosphatase reaction buffer is included with the enzyme.

T4 DNA Ligase, 1 unit/ $\mu \mathrm{L}$ (Invitrogen). 5X Ligase Buffer is included with the enzyme.

Spin-column nucleotide removal kit (for DNA purification after enzymatic reactions) (Qiagen or similar)

Spin-column plasmid miniprep kit (Qiagen or similar)

One Shot ${ }^{\circledR}$ TOP10 Electrocomp ${ }^{\mathrm{TM}}$ E. coli cells (Invitrogen)

S.O.C. broth (Invitrogen)

EZ-Tn5 ${ }^{\text {TM }}<$ KAN-2> Insertion Kit (EpiCentre Biotechnologies, Madison, WI)

Ampicillin sodium salt (Sigma, St. Louis, MO)

LB broth and LB agar (BD Difco, Franklin Lakes, NJ)

Kanamycin disulfate salt (Sigma)

5-bromo-4-chloro-3-indolyl- $\beta$-D-galactopyranoside (X-gal) (Sigma)

15-mL snap-cap tubes (VWR, Radnor, PA)

Sterile L-shaped spreaders, plastic or glass

Sterile toothpicks or disposable $1-\mu \mathrm{L}$ inoculating loops (VWR) 
Sterile $80 \%$ glycerol

Electroporator (Gene Pulser II/Pulse Controller Plus [Bio-Rad, Hercules, CA] or similar)

0.2-cm-gap Gene Pulser electroporation cuvettes (Bio-Rad)

\subsubsection{Materials for screening of disrupted target gene sequences}

T. denitrificans-specific primers (to screen for clones with the correct placement of the EZ-Tn5 $5^{\mathrm{TM}}<\mathrm{KAN}$ -

2> transposon within the $T$. denitrificans gene)

Forward primer for $T$. denitrificans sequence that lies upstream of sequence used for homologous recombination

Reverse primer for $T$. denitrificans sequence that lies downstream of sequence used for homologous recombination

Design primers such that they may be used in conjunction with EZ-Tn5 ${ }^{\mathrm{TM}} \mathrm{KAN}-2$ forward and reverse primers

EZ-Tn5 ${ }^{\mathrm{TM}}$ KAN-2 primers, forward and reverse (these are supplied in limited quantity in the EZ-Tn5 ${ }^{\mathrm{TM}}$ $<$ KAN-2> Insertion Kit)

KAN-2 FP-1 Forward Primer ACCTACAACAAAGCTCTCATCAACC

KAN-2 RP-1 Reverse Primer GCAATGTAACATCAGAGATTTTGAG

Spin-column PCR purification kit (Qiagen or similar)

Spin-column plasmid miniprep kit (Qiagen or similar)

\subsubsection{Materials for preparation of electrocompetent $T$. denitrificans cells}

Modified M9 Medium (see Section 2.3)

250-mL centrifuge tubes

\subsubsection{Materials for transformation of disrupted genes into T. denitrificans}

Modified M9 Medium (see Section 2.3)

Kanamycin disulfate salt 
Modified M9 Medium agar plates with and without $50 \mu \mathrm{g} / \mathrm{mL}$ kanamycin

Purified Agar (Oxoid, Hampshire, United Kingdom)

Electroporator (Bio-Rad Gene Pulser II/Pulse Controller Plus or similar)

0.2-cm-gap Gene Pulser electroporation cuvettes (Bio-Rad)

\subsubsection{Materials for confirmation of proper construction of insertion mutants}

T. denitrificans-specific primers

Forward primer for $T$. denitrificans sequence that lies upstream of sequence created and used for homologous recombination

Reverse primer for $T$. denitrificans sequence that lies downstream of sequence created and used for homologous recombination

\subsubsection{Materials for construction of complementation vector with $T$. denitrificans gene of} $\underline{\text { interest }}$

T. denitrificans-specific primers

Forward primer for blunt-ended cloning, phosphorylated; gene of interest for insertion into complementation vector

Reverse primer for blunt-ended cloning, phosphorylated; gene of interest for insertion into complementation vector

pUC19 MCS forward and reverse primers listed in Section 3.2.3

Phusion PCR kit (Finnzymes, Espoo, Finland).

Hpal restriction enzyme, 5000 units/mL (New England Biolabs). 10X NEBuffer 4 is included with the enzyme.

Antarctic Phosphatase, 5000 units/mL (New England Biolabs). 10X Antarctic Phosphatase reaction buffer is included with the enzyme.

T4 DNA Ligase, 1 unit/ $\mu \mathrm{L}$ (Invitrogen). 5X T4 DNA Ligase Buffer is included with the enzyme. 
Optional: End-It ${ }^{\mathrm{TM}}$ DNA End-Repair Kit (EpiCentre Biotechnologies)

Gentamicin sulfate salt (Sigma)

LB broth and LB agar with gentamicin $50 \mu \mathrm{g} / \mathrm{mL}$

Terrific Broth (BD Difco)

\subsubsection{Materials for confirmation of genotype of complemented mutants}

Modified M9 Medium agar plates containing $50 \mu \mathrm{g} / \mathrm{mL}$ gentamicin

Optional: Ndel or Stul restriction enzymes (or other appropriate single-site cutter for complementation vector

Spin-column plasmid miniprep kit (Qiagen or similar)

T. denitrificans-specific primers used in Section 3.2.7

T. denitrificans-specific reverse primer used in Section 3.3.1

pUC19 MCS reverse primer listed in Section 3.2.3

\subsection{Growth medium for T. denitrificans}

Two versions of growth medium for T. denitrificans are described here. The Anaerobic Td Medium is made rigorously anoxic and has been used for physiological, transcriptomic, and proteomic studies under denitrifying conditions. The Modified M9 Medium for T. denitrificans is less demanding to prepare because it does not require strict anaerobic technique, but is appropriate for the genetic manipulations described in this chapter.

\subsubsection{Anaerobic Td Medium (8)}

1. Boil $1 \mathrm{~L}$ of ultrapure water (18 $\mathrm{M} \Omega$ resistance; see Note 2$)$ for $30 \mathrm{~min}$

2. Add boiled water (still hot) to the following solids in an appropriate glass container: $5 \mathrm{~g}$ $\mathrm{Na}_{2} \mathrm{~S}_{2} \mathrm{O}_{3} \cdot 5 \mathrm{H}_{2} \mathrm{O}, 2 \mathrm{~g} \mathrm{KNO}_{3}, 2 \mathrm{~g} \mathrm{KH}_{2} \mathrm{PO}_{4}, 1 \mathrm{~g} \mathrm{NH}_{4} \mathrm{Cl}, 0.8 \mathrm{~g} \mathrm{MgSO}_{4} \cdot 7 \mathrm{H}_{2} \mathrm{O}$. Mix well.

3. Prepare an anaerobic solution of $1 \mathrm{M} \mathrm{NaHCO}_{3}$ as follows. Weigh $2.52 \mathrm{~g}$ of $\mathrm{NaHCO}_{3}$ into a $120-\mathrm{mL}$ serum bottle. Weigh in $30 \mathrm{~mL}$ of boiling ultrapure water. Seal the serum bottle rapidly with 
butyl rubber stopper and aluminum crimp seal and vacuum-gas three times with an anaerobic mixture of $90 \% \mathrm{~N}_{2}, 10 \% \mathrm{CO}_{2}$. This will require an anaerobic gassing station with a vacuum source. The solution should bubble during the vacuum phase.

4. Autoclave $\left(121^{\circ} \mathrm{C}, 30 \mathrm{~min}\right)$ the $1 \mathrm{~L}$ of medium in an appropriate container for anaerobic medium preparation (19) and the serum bottle containing the $1 \mathrm{M} \mathrm{NaHCO}_{3}$.

5. After autoclaving, handle the serum bottle with care, as its contents will be under pressure until cool. Immediately begin anaerobic purging the $1 \mathrm{~L}$ of medium with a filtered, anaerobic mixture of $90 \% \mathrm{~N}_{2}, 10 \% \mathrm{CO}_{2}$ while cooling in an ice bath. The medium should cool to near room temperature in $25-30 \mathrm{~min}$.

6. Once the medium and $1 \mathrm{M} \mathrm{NaHCO}_{3}$ are near room temperature, seal the medium vessel and immediately transfer to an anaerobic glove box with the serum bottle containing $1 \mathrm{M} \mathrm{NaHCO}_{3}$. If the serum bottle is added to the glove box antechamber before it has cooled, there is a risk that the serum bottle will break during the vacuum phase.

7. Once the medium is inside the glove box, the $1 \mathrm{M} \mathrm{NaHCO}_{3}$ solution can be added to the medium via sterile plastic syringe. Also, add $1 \mathrm{~mL}$ each of sterile, anaerobic vitamin and trace element solutions \# 1 (nonchelated trace elements), \#4 (selenite-tungstate), \#6 (vitamins), \#7 (thiamine), and \#8 (vitamin $B_{12}$ ) as described by Widdel and Bak (19), or the equivalent. Finally, while stirring, add $0.5 \mathrm{~mL}$ of sterile, anaerobic $0.1 \mathrm{M} \mathrm{CaCl}_{2}$ solution (prepared as described below).

8. Prepare sterile, anaerobic $0.1 \mathrm{M} \mathrm{CaCl}_{2}$ solution as follows. Weigh $0.735 \mathrm{~g}$ of $\mathrm{CaCl}_{2} \cdot 2 \mathrm{H}_{2} \mathrm{O}$ into a $120 \mathrm{~mL}$ serum bottle. Weigh in $50 \mathrm{~mL}$ of boiling ultrapure water. Seal the serum bottle rapidly with butyl rubber stopper and aluminum crimp seal and vacuum-gas three times with anaerobic (ultra-high purity) $\mathrm{N}_{2}$.

\subsubsection{Modified M9 Medium for T. denitrificans (11)}

Prepare $500 \mathrm{~mL}$ of Modified M9 Medium as follows: 
1. Boil $500 \mathrm{~mL}$ of ultrapurified water (18 $\mathrm{M} \Omega$ resistance) for $20 \mathrm{~min}$.

2. Transfer $450 \mathrm{~mL}$ of the boiled water to a 1-L medium bottle with stir bar and add the following salts: $1.5 \mathrm{~g} \mathrm{KH}_{2} \mathrm{PO}_{4}, 3.4 \mathrm{~g} \mathrm{Na}_{2} \mathrm{HPO}_{4} \cdot 7 \mathrm{H}_{2} \mathrm{O}$, and $0.5 \mathrm{~g} \mathrm{NH}_{4} \mathrm{Cl}$.

3. Stir solution until salts are dissolved. Transfer solution to a 500-mL graduated cylinder and add boiled water to $470 \mathrm{~mL}$ final volume.

4. Return salt solution to $1-\mathrm{L}$ medium bottle and autoclave $\left(121^{\circ} \mathrm{C}, 30 \mathrm{~min}\right)$ to sterilize. If making solid media, return the salt solution to a 1-L Erlenmeyer flask with stir bar, add $7.5 \mathrm{~g}$ of purified agar (Oxoid), mix well, and autoclave. When making solid media, do not allow solution to cool too much after autoclaving before adding the following final components, as agar will start to solidify.

Allow solution to cool after autoclaving, and add the following sterile components using aseptic technique:

a. $15 \mathrm{~mL} 1 \mathrm{M} \mathrm{NaHCO}_{3}$ (sterilized by filtration or autoclaving)

b. $10 \mathrm{~mL} 1 \mathrm{M} \mathrm{Na}_{2} \mathrm{~S}_{2} \mathrm{O}_{3}$ (sterilized by filtration or autoclaving)

c. $10 \mathrm{~mL} 1 \mathrm{M} \mathrm{KNO}_{3}$ (sterilized by filtration or autoclaving)

d. $\quad 0.4 \mathrm{~mL} 1 \mathrm{M} \mathrm{MgSO}_{4}$ (sterilized by filtration or autoclaving)

e. $\quad 0.1 \mathrm{~mL} 1 \mathrm{M} \mathrm{CaCl}_{2}$ (sterilized by filtration or autoclaving)

f. $\quad 1.33 \mathrm{~mL} 1 \mathrm{mg} / \mathrm{mL} \mathrm{FeCl} \cdot 6 \mathrm{H}_{2} \mathrm{O}$ (filter sterilized)

g. $7 \mu \mathrm{L} 50 \mathrm{mM} \mathrm{CuSO}_{4}$ (filter sterilized)

h. $0.5 \mathrm{~mL}$ of vitamin stock solution \#6 (19) (filter sterilized, stored at $4^{\circ} \mathrm{C}$ )

[In a $10 \mathrm{mM}$ phosphate buffer (pH 7.1): $p$-aminobenzoate (40 mg/L), D(+)-biotin (10 mg/L), nicotinic acid (100 mg/L), calcium D(+)-pantothenate $(50 \mathrm{mg} / \mathrm{L})$, pyridoxine dihydrochloride (150 mg/L).]

i. $\quad 0.5 \mathrm{~mL}$ of $50 \mathrm{mg} / \mathrm{L}$ vitamin $\mathrm{B}_{12}$ (filter sterilized, stored at $4^{\circ} \mathrm{C}$ ) 
j. $\quad 0.5 \mathrm{~mL}$ of $100 \mathrm{mg} / \mathrm{L}$ thiamine (filter sterilized, stored at $4^{\circ} \mathrm{C}$ ) 


\section{Methods}

\subsection{Cultivation of T. denitrificans}

This section addresses anaerobic cultivation of $T$. denitrificans (under denitrifying conditions) in liquid media and on solid media. Growth of suspended cultures under strictly anaerobic conditions has been used for physiological, transcriptomic, and proteomic studies. Less rigorous anaerobic conditions have been used for work involving genetic manipulations (e.g., to prepare electrocompetent $T$.

denitrificans cells; growing $T$. denitrificans cells for plasmid preparations). Note that since growth yields of this chemolithoautotrophic bacterium are much lower than for bacteria (such as E. coli) commonly used for genetic manipulation (stationary-phase $\mathrm{OD}_{600}$ is in the range of 0.1 to 0.2 ), relatively large volumes of $T$. denitrificans culture will typically be needed to acquire sufficient genomic DNA, plasmid DNA, mRNA, or protein for experiments.

Anaerobic conditions appear to be necessary for reliable growth on agar plates. When plates are incubated aerobically, S-containing precipitates appear. Poor growth on plates under aerobic conditions may be partially due to low $\mathrm{pH}$ conditions resulting from aerobic (potentially abiotic) oxidation of reduced S-containing compounds, although the cause for such poor growth has not been specifically investigated (to our knowledge).

\subsubsection{Cultivation of $T$. denitrificans under denitrifying conditions in liquid medium}

1. Successful anaerobic cultivation of T. denitrificans has been carried out in glove boxes (e.g., Coy Laboratory Products, Grass Lake, MI) maintained at $30^{\circ} \mathrm{C}$ with a nominal gas composition of $90 \%$ $\mathrm{N}_{2}-10 \% \mathrm{CO}_{2}-10 \% \mathrm{H}_{2}$. Shaking is not required for anaerobic cultivation. The glass and plastic materials used to contain or manipulate the cultures should be allowed to degas in the glove box for at least one day before use.

2. It is convenient to use Balch tubes for growth and transfer of smaller-volume cultures $(<25 \mathrm{~mL})$. Clean, dry tubes can be left in an anaerobic glove box to release residual oxygen, then crimp- 
sealed in the glove box with butyl rubber stoppers and aluminum crimp seals, autoclaved, and returned to the glove box. Anaerobic Td Medium (Section 2.3) can then be injected into the sealed, anaerobic, sterile tubes.

3. Ampoules from the American Type Culture Collection (ATCC strain 25259) containing lyophilized T. denitrificans can be opened as described in the ATCC instructions (preferably in an anaerobic glove box). The culture can be re-hydrated with $0.5 \mathrm{~mL}$ of Anaerobic Td Medium delivered from a Balch tube (originally containing $5 \mathrm{~mL}$ of medium) into the ATCC culture via sterile syringe, resuspended, and then injected back into the Balch tube. After 3 days, the culture should be ready for transfer (as a $5 \%$ inoculum).

4. Alternatively, wild-type or mutant $T$. denitrificans colonies (e.g., from streaked out glycerol freezer stocks) can be used as inocula. Inside the anaerobic glove box, colonies can be inoculated into 0.5 or $1 \mathrm{~mL}$ of Anaerobic Td Medium (with appropriate antibiotics). These cultures should be ready for $5 \%$ transfer within 2 days. A good indication that a culture is ready for transfer is the appearance of $\mathrm{N}_{2}$ bubbles on the side of the tube being used for growth (and turbidity, although full-grown $T$. denitrificans cultures are much less turbid than organoheterotrophic bacterial cultures typically studied).

5. It is recommended that all cultures be initiated under strictly anaerobic conditions, even if they will ultimately be transferred to less rigorously anaerobic conditions for larger volume culture.

\subsubsection{Benchtop cultivation of T. denitrificans under less stringent anaerobic conditions in} liquid medium

1. Using the Modified M9 Medium described in Section 2.3 and static cultivation on the benchtop, T. denitrificans can be cultivated to provide cultures for making electrocompetent cells, etc.

2. As $T$. denitrificans is a facultative anaerobe, it can readily deplete residual oxygen in the medium and then sustain denitrifying conditions. It is best not to agitate the culture on the benchtop, 
which would re-supply oxygen. Cultivation under denitrifying conditions is generally less stressful for these bacteria than under aerobic conditions, in part because aerobic thiosulfate oxidation will drive the $\mathrm{pH}$ from 7 to $\sim 5$. This follows from the stoichiometry of thiosulfate oxidation, which yields five-fold more protons per mole of thiosulfate under aerobic than denitrifying conditions.

\subsubsection{Anaerobic growth on agar plates}

1. Create agar plates for $T$. denitrificans using the Modified M9 recipe for solid media found in Section 2.3. Allow the plates to dry on the bench top or in a laminar flow biosafety cabinet, until any condensation or residual water on the Petri dish lid or surface of the agar has evaporated.

2. For spread plating of liquid cell suspensions: Transfer $50-100 \mu \mathrm{L}$ of the $T$. denitrificans cell suspension to an agar plate and use an L-shaped spreader to spread the cell suspension uniformly across the surface of the plate until the liquid portion of the cell suspension has completely been absorbed into the agar. Do this by continually rotating the Petri dish while applying gentle pressure and a small amount of back-and-forth linear motion with the Lspreader. Try not to push the cell suspension to the edges of the plate, as it will become more difficult to identify isolated colonies on the edges of the agar plate.

3. For streak-plating colonies: Isolated colonies of $T$. denitrificans may be transferred and streakplated by picking an isolated $T$. denitrificans colony with an inoculating loop and making a primary streak across one half of the Petri dish containing solid $T$. denitrificans media. Pass a flame sterilized or second sterile disposable loop four to five times through the primary streak and create a secondary streak across the second half of the solid medium. Tertiary streaks are usually not necessary to create isolated colonies when growing $T$. denitrificans.

4. Invert plates, place in an anaerobic glove box, and incubate at $30^{\circ} \mathrm{C}$ until isolated colonies are observed. This will take approximately 5-10 days. 
5. Let colonies grow to approximately $2 \mathrm{~mm}$ in diameter before transferring or screening.

\subsection{Generation of insertion mutants in T. denitrificans}

\section{$\underline{\text { 3.2.1 Isolation of genomic DNA from } T \text {. denitrificans }}$}

(see Note 3; see (20))

1. As described in Section 3.1, grow T. denitrificans cells in Anaerobic Td Medium or Modified M9 Medium, to late exponential phase $\left(\mathrm{OD}_{600} \sim 0.1\right.$ or $\sim 10^{8}$ cells $\left./ \mathrm{mL}\right)$. Using this modified $\mathrm{CTAB}$ extraction method, it should be possible to extract a minimum of $0.5-1 \mu \mathrm{g}$ of DNA per $10^{8} \mathrm{~T}$. denitrificans cells.

2. Preheat two water baths, one to $37^{\circ} \mathrm{C}$ and one to $65^{\circ} \mathrm{C}$.

3. Begin heating $10 \% \mathrm{CTAB} / 0.7 \mathrm{M} \mathrm{NaCl}$ solution in the $65^{\circ} \mathrm{C}$ water bath.

4. Transfer required volume of $T$. denitrificans cells into a centrifuge tube, and spin cells at $8000 \times g$ for $5 \mathrm{~min}$.

5. Decant supernatant, and resuspend cells in TE. Use approximately $1 \mathrm{~mL}$ TE per $10^{9}$ cells of $T$. denitrificans in the original cell suspension. Adjust the cell suspension to an $\mathrm{OD}_{600}$ of approximately 1.0 .

6. Transfer $14.8 \mathrm{~mL}$ of the cell suspension to a clean and chemically resistant, $50-\mathrm{mL}$, screw-cap centrifuge tube. Throughout this protocol, use a centrifuge tube that is phenol-, chloroform-, and alcohol-resistant. The volumes listed in this protocol can be proportionally adjusted for differing volumes of cell suspension.

7. Add $800 \mu \mathrm{L} 10 \%$ SDS and mix gently by inversion.

8. Add $32 \mu \mathrm{L} 50 \mathrm{mg} / \mathrm{mL}$ Proteinase $\mathrm{K}$ and mix gently by inversion.

9. Incubate for 1 hour at $37^{\circ} \mathrm{C}$. Mix gently by inversion after 30 min of $37^{\circ} \mathrm{C}$ incubation.

10. Add $2 \mathrm{~mL} 5 \mathrm{M} \mathrm{NaCl}$, and mix gently by inversion. 
11. Add $2 \mathrm{~mL} 10 \% \mathrm{CTAB} / 0.7 \mathrm{M} \mathrm{NaCl}$ solution that has been heated to $65^{\circ} \mathrm{C}$, and mix gently by inversion.

12. Incubate suspension at $65^{\circ} \mathrm{C}$ for $10 \mathrm{~min}$.

13. Add $10 \mathrm{~mL}$ of chloroform:isoamyl alcohol (24:1) and shake tube to mix.

14. Spin in centrifuge at $5000 \times g$ at room temperature for $10 \mathrm{~min}$.

15. After spinning, two layers should have formed, a top aqueous layer containing nucleic acids, and a bottom organic layer containing proteins and chloroform. Remove the top aqueous layer and transfer to a clean 50-mL, screw-cap centrifuge tube. While removing the top aqueous layer, take care to not disturb or take up any of the bottom organic layer. Err on the side of leaving behind a small amount of aqueous layer if necessary

16. Add $10 \mathrm{~mL}$ of phenol:chloroform:isoamyl alcohol (25:24:1) and shake tube to mix.

17. Spin in centrifuge at $5000 \times g$ at room temperature for $10 \mathrm{~min}$.

18. Repeat steps 15-17.

19. Remove top aqueous layer and transfer to a clean $50-\mathrm{mL}$, screw-cap centrifuge tube.

20. Add 0.6 volume of $99 \%$ Isopropanol.

21. Mix tube contents by gently inverting tube end over end until precipitated DNA appears. DNA should appear as a stringy white mass that comes out of solution.

22. Remove DNA by spooling around a pipette tip and transferring to a clean $50-\mathrm{mL}$ centrifuge tube.

23. Wash DNA twice with 5-mL portions of $70 \%$ ethanol. Resuspension of the DNA is not necessary for an efficient wash. Simply add 70\% ethanol and swirl tube gently, making sure precipitated DNA mass is in full contact with ethanol. Remove the first $5 \mathrm{~mL}$ ethanol wash by aspiration with pipette, taking care to not remove DNA. Add another $5 \mathrm{~mL}$ of $70 \%$ ethanol and again remove by aspiration with pipette. 
24. Briefly spin centrifuge tube after $2^{\text {nd }}$ wash, remove as much ethanol as possible, and allow pellet to air dry at room temperature. Do not allow DNA pellet to dry for too long, as resuspension of the DNA will become more difficult.

25. Resuspend pellet in $1 \mathrm{~mL} \mathrm{TE,} \mathrm{pH}$ 8.0. If the DNA pellet does not resuspend easily, warming the TE and DNA gently to $37^{\circ} \mathrm{C}$, or incubating the DNA in TE at room temperature for $1-2$ hours, may aid in resuspension.

26. Add $20 \mu \mathrm{L} 5 \mu \mathrm{g} / \mu \mathrm{L}$ RNase $\mathrm{A}$, and mix gently.

27. Incubate the solution at $37^{\circ} \mathrm{C}$ for $30 \mathrm{~min}$.

28. Add $9 \mathrm{~mL}$ of TE, $\mathrm{pH}$ 8.0. Mix tube gently.

29. Add $10 \mathrm{~mL}$ of phenol:chloroform:isoamyl alcohol (25:24:1) and mix gently by inverting tube end over end.

30. Spin in centrifuge at $5000 \times g$ at room temperature for $10 \mathrm{~min}$.

31. Remove top aqueous layer and transfer to a clean $50 \mathrm{~mL}$ centrifuge tube.

32. Add 0.6 volumes of $99 \%$ Isopropanol and 2 -volumes of $5 \mathrm{M} \mathrm{NaCl}$. Invert tube end over end several times to mix.

33. Spin in centrifuge at $14000 \times g$ at room temperature for $10 \mathrm{~min}$.

34. Remove supernatant, taking care to not dislodge DNA pellet.

35. Wash pellet four times with $10 \mathrm{~mL}$ portions of $70 \%$ ethanol; resuspension of the pellet is not necessary to wash.

36. Spin in centrifuge at $14000 \times g$ at room temperature for $2 \mathrm{~min}$. Remove as much $70 \%$ ethanol as possible from around the DNA pellet.

37. Let the DNA pellet air dry at room temperature.

38. Resuspend in $500 \mu \mathrm{LTE}, \mathrm{pH} 8.0$. 
39. Determine DNA concentration and purity by $A_{260} / A_{280}$ reading or by fluorimetry (e.g., PicoGreen ${ }^{\circledR}$ assay [Invitrogen]).

40. Aliquot into smaller volumes and store at $-20^{\circ} \mathrm{C}$ or $4^{\circ} \mathrm{C}$.

\subsubsection{Amplification of target genes and flanking DNA from $T$. denitrificans}

1. As a template, use T. denitrificans genomic DNA isolated by CTAB protocol (Section 3.2.1) at a concentration of $1-50 \mathrm{ng} / \mu \mathrm{l}$.

2. Design forward and reverse primers for the T. denitrificans gene of interest; include Kpnl restriction sites on the $5^{\prime}$ ends for use in ligating the resulting PCR product with pUC19 cut with Kpnl. The forward primer should be positioned 1000 - 1500 bp upstream of the start codon of the gene of interest. The reverse primer should be positioned $1000-1500 \mathrm{bp}$ downstream of the start codon. The final product for homologous recombination should be $2.5 \mathrm{~kb}$ or greater. At least 3 and preferably 6 bases are required at the $5^{\prime}$ ends of Kpnl restriction sites. Additional bases at the $5^{\prime}$ end can be randomly selected ensuring that an additional Kpnl site is not generated. See Note 4-6.

3. Prepare the PCR master mix using the Advantage-GC 2 Genomic PCR Kit and the following components for a $25-\mu \mathrm{L}$ PCR. Add the following components in the order listed into a $200-\mu \mathrm{L}$ PCR tube: (a) $13.5 \mu \mathrm{L}$ PCR-grade water, (b) $5 \mu \mathrm{L}$ 5X GC2 Buffer, (c) $2.5 \mu \mathrm{L} 5 \mathrm{M}$ GC Melt, (d) $0.5 \mu \mathrm{L}$ 50X dNTPs, (e) $1 \mu \mathrm{L} 10 \mu \mathrm{M}$ forward primer (primer $\mathrm{T}_{\mathrm{m}}$ should be within 2-3 degrees Celsius of the reverse primer $\mathrm{T}_{\mathrm{m}}$ ), (f) $1 \mu \mathrm{L} 10 \mu \mathrm{M}$ reverse primer, (g) $1 \mu \mathrm{L} T$. denitrificans genomic DNA (1$50 \mathrm{ng} / \mu \mathrm{L}$ ), (h) $0.5 \mu \mathrm{L} 50 \mathrm{X}$ polymerase (mix tube gently before adding polymerase).

4. Mix tube gently and centrifuge briefly to bring components to the bottom of the tube.

5. Cap tube and place in thermal cycler.

6. Program a thermal cycler for the following cycling parameters: (A) $98^{\circ} \mathrm{C}$ hold for $2 \mathrm{~min}$; (B) 35 cycles of the following: (i) $98^{\circ} \mathrm{C}$ for $10 \mathrm{sec}$, (ii) $30 \mathrm{sec}$ at the annealing temperature, about 3-5 
degrees Celsius below the $T_{m}$ of the primers used (the annealing temperature is typically $50-$ $65^{\circ} \mathrm{C}$ (Note 7)), (iii) $72^{\circ} \mathrm{C}$ for 1 min per $1 \mathrm{~kb}$ of expected amplicon size (Note 8); (C) $72^{\circ} \mathrm{C}$ final extension (extension time dependent on expected amplicon size (Note 8)); (D) $4^{\circ} \mathrm{C}$ hold upon completion.

7. Run $10 \mu \mathrm{L}$ of the PCR on a $1.2 \%$ agarose gel. Include a DNA molecular weight marker with band sizes bracketing the expected size of the PCR product (Note 9).

8. Analyze by staining gel with an appropriate double-stranded DNA intercalating dye (such as ethidium bromide or SYBR Green) and image using a gel-imaging system with the correct excitation and emission filters for the DNA intercalating dye used. Use this same method for all remaining gel analyses.

9. If expected amplicon size is present, repeat the PCR reaction with the same thermal cycling conditions, scaling up the amount of master mix to include enough components for five to ten $25-\mu \mathrm{L}$ PCR reactions. Thermal cycle the reactions individually at $25 \mu \mathrm{L}$, then pool the reactions together in a clean 1.7-mL microfuge tube. Purify the pooled reactions using a spin-column PCR purification kit. Choose an elution volume that will yield a final DNA concentration of 50-100 $\mathrm{ng} / \mu \mathrm{L}$. (Note 10, 11)

10. Once the PCR product has been isolated and purified, run $2-3 \mu \mathrm{L}$ of the product on a $1.2 \%$ agarose gel with a DNA molecular weight and mass marker. Check for a single clean band of the expected size product, and use the DNA molecular weight and mass marker to estimate the concentration of the DNA product. Ideally the concentration of the product should be approximately $50-100 \mathrm{ng} / \mu \mathrm{L}$. If the concentration is too dilute, the DNA may be concentrated by repurifying the DNA, this time eluting the DNA from the spin-column in a smaller volume then previously used. (Note 12) 
11. Prepare the Kpnl digest reaction by adding the following components to a clean $0.5-\mathrm{mL}$ microfuge tube in the order listed: (a) nuclease-free water to $50 \mu \mathrm{L}$, (b) $5 \mu \mathrm{L} 10 \mathrm{X} \mathrm{Kpnl} \mathrm{restriction}$ enzyme buffer, (c) $0.5 \mu \mathrm{L}$ 100X Bovine Serum Albumin (10 mg/mL BSA), (d) $1 \mu \mathrm{L} \mathrm{Kpnl,} 10000$ units/mL, (e) 500 ng $-2.5 \mu \mathrm{g}$ T. denitrificans PCR product.

12. Mix gently, but thoroughly, and centrifuge briefly to bring contents to bottom of tube.

13. Incubate reaction at $37^{\circ} \mathrm{C}$ for $1-2$ hours.

14. Add another $1 \mu \mathrm{L} \mathrm{Kpnl,} \mathrm{mix} \mathrm{gently,} \mathrm{and} \mathrm{digest} \mathrm{for} \mathrm{another} \mathrm{1-2} \mathrm{hours.}$

15. Purify reaction using a spin-column nucleotide removal kit and elute in a volume to give a final DNA concentration of approximately $10-50 \mathrm{ng} / \mu \mathrm{L}$. (see Note 12)

16. Run 3-5 $\mu \mathrm{L}$ on a $1.2 \%$ agarose gel with a DNA molecular weight and mass marker to get an approximate concentration of the Kpnl-digested T. denitrificans PCR product.

17. Adjust the final concentration of the Kpnl-digested PCR product to approximately $10-50 \mathrm{ng} / \mu \mathrm{L}$.

\section{$\underline{3.2 .3 \text { In-vitro transposition of target genes }}$}

A. Preparation of pUC19 Kpnl-digested plasmid:

1. Digest approximately 1-3 $\mu \mathrm{g}$ of pUC19 with Kpnl restriction enzyme.

2. Prepare the Kpnl digest reaction by adding the following components to a clean $0.5-\mathrm{mL}$ microfuge tube in the order listed: (a) nuclease-free water to $50 \mu \mathrm{L}$, (b) $5 \mu \mathrm{L} 10 \mathrm{X} \mathrm{Kpnl} \mathrm{restriction}$ enzyme buffer, (c) $0.5 \mu \mathrm{L} 100 \mathrm{X}$ Bovine Serum Albumin, (d) $1 \mu \mathrm{L} \mathrm{Kpnl,} \mathrm{10,000} \mathrm{units/ \mu L,} \mathrm{(e)} \mathrm{1-3} \mu \mathrm{g}$ pUC19 DNA.

3. Mix gently, but thoroughly, and centrifuge briefly to bring components to bottom of tube.

4. Incubate reaction at $37^{\circ} \mathrm{C}$ for $2-4$ hours.

5. Add $1 \mu \mathrm{L} \mathrm{Kpnl,} \mathrm{mix} \mathrm{gently,} \mathrm{and} \mathrm{digest} \mathrm{for} \mathrm{another} \mathrm{1-2} \mathrm{hours.}$

B. Dephosphorylation of Kpnl-digested pUC19

Kpnl-digested DNA does not need to be purified before treatment with Antarctic Phosphatase. 
1. Prepare the dephosphorylation reaction by adding the following components to a clean $0.5-\mathrm{mL}$ microfuge tube in the order listed: (a) $40 \mu \mathrm{L}$ pUC19 Kpnl digest, (b) $4 \mu \mathrm{L}$ nuclease-free water, (c) $5 \mu \mathrm{L}$ 10X Antarctic Phosphatase buffer, (d) $1 \mu \mathrm{L}$ Antarctic Phosphatase.

2. Mix gently and centrifuge briefly to bring contents to the bottom of the tube.

3. Incubate reaction at $37^{\circ} \mathrm{C}$ for 1.5 hours.

4. Incubate reaction at $65^{\circ} \mathrm{C}$ for $10 \mathrm{~min}$ in order to heat denature the Antarctic Phosphatase.

C. Gel purification of Kpnl-digested and dephosphorylated pUC19

1. Use a preparative gel comb to create a $1.2 \%$ agarose preparative gel for purifying the Kpnldigested and dephosphorylated pUC19 vector.

2. Run the total volume of digested/dephosphorylated pUC19 on the preparative gel along with an appropriately sized DNA molecular weight marker.

3. Stain and image gel. Use a razor blade or gel cutting tool to cut and remove the digested pUC19 band from the gel. The correct band should be approximately 2686 bp in size. (Note 13) [When using UV light for gel analysis and subsequent DNA band extraction, be sure to wear the appropriate eye and face shielding for the wavelength of light used.]

4. Purify the DNA using a spin-column gel purification kit.

5. Elute the DNA from the column with $50 \mu \mathrm{L}$ of buffer provided with the kit. (Note 14)

6. Analyze $2-5 \mu \mathrm{L}$ of the eluted pUC19 DNA on a $1.2 \%$ agarose gel to check for the appropriate size, presence of one band (representing the presence of digested plasmid DNA only), and concentration of pUC19. Run the DNA with a molecular weight ruler that also gives approximate mass amounts. This is useful for determining the concentration of digested pUC19 DNA for future ligation reactions. The concentration may also be determined by using $A_{260}$ measurements or an appropriate fluorimetric method. 
D. Ligation and transformation of pUC19 with $T$. denitrificans Kpnl-digested and purified PCR product (see Section 3.2.2)

1. Prepare the ligation reaction by adding the following components to a clean $0.5-\mathrm{mL}$ microfuge tube in the order listed: (a) DNase/RNase free water to $20 \mu \mathrm{L}$, (b) $2 \mu \mathrm{L}$ 10X T4 DNA Ligase Buffer, (c) approximately 20-30 ng (or 3-30 fmol) pUC19 (Kpnl-digested, dephosphorylated, purified), (d) T. denitrificans PCR product (gene of interest) created in Section 3.2.2; Kpnl-digested and purified; add to a final molar amount 3 times that of pUC19 (molar ratio of 3:1 insert:vector), (e) $1 \mu \mathrm{L}$ T4 DNA Ligase, (0.1 units/ $\mu \mathrm{L})$. (Note 15, 16)

2. Optional: Prepare control ligations. (Note 17)

3. Mix tube gently and centrifuge briefly to bring the contents to the bottom of the tube.

4. Incubate reaction at $16^{\circ} \mathrm{C}$ overnight or for at least 1 hour at room temperature.

5. Inactivate the T4 DNA Ligase by heating the reaction to $70^{\circ} \mathrm{C}$ for $10 \mathrm{~min}$.

6. Purify the ligation reaction using a spin-column nucleotide removal kit.

7. Elute the reaction in $30 \mu \mathrm{L}$ of elution buffer provided with spin-column kit.

8. Store reaction on ice or at $4^{\circ} \mathrm{C}$ until ready for electroporation.

9. Place electroporation cuvettes on ice.

10. Set the electroporator to the following settings (Note 18): (a) Resistance $=200$ ohms, (b) Capacitance $=25 \mu \mathrm{F}$, (c) Time $=5 \mathrm{~ms}$, (d) Current $=12.5 \mathrm{kV} / \mathrm{cm}$.

11. Thaw One Shot ${ }^{\circledR}$ Top10 Electrocomp ${ }^{\mathrm{TM}}$ E. coli cells on ice.

12. Pipette $50 \mu \mathrm{L}$ of cells into a chilled $1.5-\mathrm{mL}$ microfuge tube, and keep on ice.

13. Pipette 1-3 $\mu \mathrm{L}$ of ligation reaction into a microfuge tube containing cells, and mix gently.

14. Optional: Control reactions (Note 17)

15. Pipette the cells/ligation mixture into a chilled electroporation cuvette.

16. Dry cuvette off with paper towel or tissue. 
17. Place the cuvette into the electroporator, and apply electrical pulse (Note 19).

18. Immediately after pulsing, pipette $250 \mu \mathrm{L}$ of S.O.C. medium into the cuvette.

19. Transfer the medium/cells to a sterile $15-\mathrm{mL}$ snap-cap tube. Do not tightly cap the tube (this allows for better aeration of the culture).

20. Incubate at $37^{\circ} \mathrm{C}, 200 \mathrm{rpm}$, for exactly one hour.

21. Spread 50-100 $\mu \mathrm{L}$ of cells on LB agar plates containing $100 \mu \mathrm{g} / \mathrm{mL}$ ampicillin and $50 \mu \mathrm{g} / \mathrm{mL} \mathrm{X}$-gal. All $250 \mu \mathrm{L}$ of medium/cells may be plated over a series of plates, or a fraction may be plated and the rest stored at $4^{\circ} \mathrm{C}$. (Note 20)

22. Incubate plates overnight at $37^{\circ} \mathrm{C}$.

23. Check on plates the following morning. A mixture of blue colonies (representing no insert in vector) and white colonies (representing presence of insert in vector) should be present. (Note 21).

E. Transformant screening and transposon plasmid preparation

1. Use PCR to screen for the presence of insert in pUC19 by using the following protocol: $(A)$ Prepare PCR master mix using the Advantage-GC 2 Genomic PCR Kit and the following components for a $25-\mu \mathrm{L}$ PCR. Multiply each of these individual volumes by the number of clones that will be screened, and prepare master mix in a 1.7-mL microfuge tube: (i) $14.5 \mu \mathrm{L}$ PCR-grade water, (ii) $5 \mu \mathrm{L}$ 5X GC2 Buffer, (iii) $2.5 \mu \mathrm{L} 5 \mathrm{M}$ GC Melt, (iv) $1 \mu \mathrm{L} 10 \mu \mathrm{M}$ pUC19 MCS forward primer, (v) $1 \mu \mathrm{L} 10 \mu \mathrm{M}$ pUC19 MCS reverse primer, (vi) $0.5 \mu \mathrm{L}$ 50X dNTPs (mix tube contents before adding the polymerase), (vii) $0.5 \mu \mathrm{L} 50 \mathrm{X}$ polymerase (mix tube gently and spin briefly). (B) Pipette $25 \mu \mathrm{L}$ of the PCR master mix into a $200-\mu \mathrm{L}$ PCR tube. Do this for as many reactions as needed. (C) Use a sterile toothpick, pipette tip, or inoculation loop to transfer a portion of a white colony from the agar plate containing colonies from the electroporation. Spread the cells onto another LB agar plate containing $100 \mu \mathrm{g} / \mathrm{mL}$ ampicillin, and number the plate in order to 
track the clone. Dividing plates into numbered grids is a useful way to track numerous clones. (D) Scrape another small portion (barely enough to be seen on the toothpick or loop) of the same colony, and place it into one of the $200-\mu \mathrm{L}$ PCR tubes containing master mix. Try to gently resuspend the cells in the master mix, but do not splash master mix or potentially damage the DNA polymerase by resuspending the cells too roughly. (E) When all clones have been transferred, cap the PCR tubes and place in a thermal cycler. Use the same thermal cycling parameters that were used to create the insert by PCR in Section 3.2.2. A $60^{\circ} \mathrm{C}$ annealing temperature should be used with the pUC19 MCS primers mentioned above. (F) Incubate the newly plated cells at $37^{\circ} \mathrm{C}$ overnight. The original plate of transformed cells may be kept and stored at $4^{\circ} \mathrm{C}$ in case more clones are needed for screening.

2. When thermal cycling is complete, analyze the PCR reactions by gel electrophoresis. Look for the presence of the same size amplicon as seen after the initial PCR of the $T$. denitrificans gene of interest (Section 3.2.2)

3. When a clone has been determined to contain the pUC19 vector with the correct size insert, use the newly plated cells to inoculate $5 \mathrm{~mL}$ of LB broth containing $100 \mu \mathrm{g} / \mathrm{mL}$ ampicillin. Incubate overnight at $37^{\circ} \mathrm{C}$ with 200-rpm shaking. (Note 22)

4. Transfer $4.5 \mathrm{~mL}$ of the overnight $E$. coli culture to a $15-\mathrm{mL}$ centrifuge tube and spin for $5 \mathrm{~min}$ at 6800 x g. Remove supernatant. (Note 23)

5. Extract the pUC19:T. denitrificans insert plasmid by use of a spin-column plasmid miniprep kit.

6. Once the pUC19:T. denitrificans insert plasmid has been isolated, determine the approximate concentration by gel electrophoresis with a molecular mass marker, $\mathrm{A}_{260}$ reading, or appropriate fluorimetric method. (Note 24, 25)

F. EZ-Tn5 ${ }^{\text {TM }}<\mathrm{KAN}-2>$ transposition 
1. Adjust the concentration of the pUC19:T. denitrificans insert plasmid to approximately 0.2 $\mu \mathrm{g} / \mu \mathrm{L}$. Using the EpiCentre EZ-Tn5 ${ }^{\mathrm{TM}}<\mathrm{KAN}-2>$ Insertion Kit, prepare the transposition reaction by adding the following components to a $0.5-\mathrm{mL}$ microfuge tube in the following order: (a) $1 \mu \mathrm{L}$ EZ-Tn5 ${ }^{\text {TM }}$ 10X Reaction Buffer, (b) $0.2 \mu \mathrm{g}$ pUC19:T. denitrificans insert plasmid, (c) molar equivalent of EZ-Tn5 ${ }^{\mathrm{TM}}<\mathrm{KAN}-2>$ Transposon (Note 26), (d) Nuclease-free water to $9 \mu \mathrm{L}$, (e) $1 \mu \mathrm{L}$ EZ-Tn5 ${ }^{\mathrm{TM}}$ Transposase.

2. Mix gently and spin briefly to bring the components to the bottom of the tube. Incubate the reaction mixture for 2 hours at $37^{\circ} \mathrm{C}$.

3. Stop the reaction by adding $1 \mu \mathrm{L} E Z-\operatorname{Tn} 5^{\mathrm{TM}} 10 \mathrm{X}$ Stop Solution. Mix the reaction and heat at $70^{\circ} \mathrm{C}$ for $10 \mathrm{~min}$.

4. Follow the same electroporation procedure as found in Section 3.2.3 (D) with the exception of using LB agar plates containing $50 \mu \mathrm{g} / \mathrm{mL}$ kanamycin in place of ampicillin for selection. X-gal is not necessary for screening. (Note 27)

\subsubsection{Screening of disrupted target gene sequences}

1. Screen kanamycin-resistant colonies resulting from transposition. Use same procedures as described in Section 3.2.3 following pUC19:T. denitrificans gene ligation electroporation. Use 50 $\mu \mathrm{g} / \mathrm{mL}$ kanamycin for selection.

2. In order to screen for clones with the correct placement of the EZ-Tn5 ${ }^{\mathrm{TM}}<\mathrm{KAN}-2>$ transposon within the $T$. denitrificans gene, use the same whole-cell screening procedure as described in Section 3.2.3. Primers specific for the $\mathrm{EZ}-\mathrm{Tn} 5^{\mathrm{TM}}<\mathrm{KAN}-2>$ transposon will be used instead of pUC19 MCS primers, and the master mix should be set up as follows: Prepare PCR master mix using the Advantage-GC 2 Genomic PCR kit and component volumes for a $25-\mu L$ PCR. Multiply each of these by the number of clones that will be screened, and mix the following components in a clean 1.7-mL microfuge tube in the order listed: (a) $14.5 \mu \mathrm{L}$ PCR-grade water, (b) $5 \mu \mathrm{L} 5 \mathrm{X}$ 
GC2 Buffer, (c) $2.5 \mu \mathrm{L} 5 \mathrm{M}$ GC Melt, (d) $1 \mu \mathrm{L} 10 \mu \mathrm{M}$ T. denitrificans-specific forward primer, (e) 1 $\mu \mathrm{L} 10 \mu \mathrm{M}$ EZ-Tn5 ${ }^{\mathrm{TM}}$ KAN-2 forward primer, (f) $0.5 \mu \mathrm{L}$ 50X dNTPs (mix tube contents before adding polymerase), (g) $0.5 \mu \mathrm{L} 50 \mathrm{X}$ polymerase (mix tube gently and centrifuge briefly to bring the components to the bottom of the tube).

3. Prepare another PCR master mix following the same directions as above, except replace the 10 $\mu \mathrm{M}$ EZ-Tn5 $5^{\mathrm{TM}} \mathrm{KAN}-2$ forward primer with the $10 \mu \mathrm{M}$ EZ-Tn5 ${ }^{\mathrm{TM}} \mathrm{KAN}-2$ reverse primer. (Note 28,

\section{9)}

4. Set up and run thermal cycling parameters using suggestions found in Section 3.2.2. Annealing temperatures and extension times depend on the $T$. denitrificans primer $\mathrm{T}_{\mathrm{m}}$ and expected amplicon size, but should be around $60-65^{\circ} \mathrm{C}$ for annealing and $1-2 \mathrm{~min}$ for extension (if the $T$. denitrificans primer being used was designed for close proximity to the ATG translation start site).

5. Run $10 \mu \mathrm{L}$ of the PCR on a $1.2 \%$ agarose gel with an appropriate DNA size marker. Look for a product that suggests EZ-Tn5 ${ }^{\mathrm{TM}}<\mathrm{KAN}-2>$ transposon insertion within $100-500$ bp of the ATG site of the $T$. denitrificans gene of interest.

6. Use the same methods found in Section 3.2.3 to culture, preserve, and isolate the plasmid of any clones that have been determined to have the correct placement of the EZ-Tn5 $5^{\mathrm{TM}}<\mathrm{KAN}-2>$ transposon within the $T$. denitrificans gene sequence.

7. Determine the exact EZ-Tn5 ${ }^{\mathrm{TM}}<\mathrm{KAN}-2>$ transposon placement within the $T$. denitrificans gene by sequencing. Use the purified plasmid of the clone(s) as template for the sequencing reactions. Sequence using the EZ-Tn5 ${ }^{\mathrm{TM}} \mathrm{KAN}-2$ forward and reverse primers. (Note 30)

8. To prepare linear, disrupted DNA for transformation into T. denitrificans, repeat protocol found in Section 3.2.2, steps 3-9. Use the same primers but adjust the thermal cycling conditions for the expected larger PCR product (the EZ-Tn5 $5^{\mathrm{TM}}<\mathrm{KAN}-2>$ transposon increases product size by 
$1221 \mathrm{bp})$. For template, use the pUC19 plasmid with the disrupted $T$. denitrificans gene created in this section. Prepare final linear DNA concentration to approximately 40 - $100 \mathrm{ng} / \mu \mathrm{L}$.

\subsubsection{Preparation of electrocompetent T. denitrificans cells}

1. Grow T. denitrificans cells in $200 \mathrm{~mL}$ Modified M9 Medium at $30^{\circ} \mathrm{C}$ without shaking. Cells should reach an optical density $(600 \mathrm{~nm})$ of 0.1 to 0.25 within 48 hours. Prepare cells immediately before electroporation. (Note 31)

2. Cool centrifuge to $4^{\circ} \mathrm{C}$. Chill sterile ultrapure water on ice. Begin chilling electroporation cuvettes on ice. (Note 32)

3. Transfer $2 \times 100 \mathrm{~mL}$ culture to $250-\mathrm{mL}$ centrifuge tubes, and spin cells at $3220 \times \mathrm{g}$ for $10 \mathrm{~min}$ at $4^{\circ} \mathrm{C}$.

4. Remove supernatant and gently resuspend each cell pellet in $50 \mathrm{~mL}$ cold, sterile ultrapure water.

5. Spin cells again at $3220 \times g$ for $10 \mathrm{~min}$ at $4^{\circ} \mathrm{C}$.

6. Remove supernatant and gently resuspend each cell pellet in $50 \mathrm{~mL}$ cold, sterile ultrapure water.

7. Spin cells again at $3220 \times g$ for $10 \mathrm{~min}$ at $4^{\circ} \mathrm{C}$.

8. Remove supernatant and gently resuspend each cell pellet in $500 \mu \mathrm{L}$ cold, sterile ultrapure water.

9. Keep cells on ice throughout washing procedure.

\subsubsection{Transformation of disrupted genes into T. denitrificans}

1. Place the following items on ice: (a) Modified M9 Medium (enough for $1 \mathrm{~mL}$ per electroporation), (b) electroporation cuvettes, (c) electrocompetent $T$. denitrificans cells, (d) DNA to be transformed into $T$. denitrificans (prepared to approximately 40-100 ng/ $\mu \mathrm{L}$; see Section 3.2.4, step 8), (e) nuclease-free water or $10 \mathrm{mM}$ Tris buffer, $\mathrm{pH} 8.0$ to be used as a negative control.

2. Set electroporator to the same settings as found in Section 3.2.3 for E. coli transformation. 
3. Pipette $50 \mu \mathrm{L}$ of freshly prepared T. denitrificans electrocompetent cells (see Section 3.2.5) into a chilled 1.7-mL microfuge tube and keep on ice.

4. Pipette 2-5 $\mu \mathrm{L}$ of DNA into a chilled microfuge tube containing $T$. denitrificans cells, and mix by gently flicking with finger.

5. Pipette cells mixed with DNA into a chilled electroporation cuvette.

6. Dry water off cuvette with a tissue or paper towel.

7. Place cuvette into the electroporator and apply electric pulse. (Note 33)

8. Immediately after pulsing, add $1 \mathrm{~mL}$ of ice-cold Modified M9 Medium (Section 2.3) to the cuvette containing cells, and place cuvette back on ice.

9. Repeat steps 3-8 for each sample, including a negative control of $2 \mu \mathrm{L}$ water or Tris buffer (no DNA added).

10. Transfer cells and media to a sterile 1.7-mL microfuge tube, and allow cells to recover for 24 hours at room temperature without shaking. The appearance of $N_{2}$ bubbles after 16-24 hours is a good sign and suggests that the $T$. denitrificans cells are active.

11. Spread $50 \mu \mathrm{L}-100 \mu \mathrm{L}$ of $T$. denitrificans cells onto Modified M9 Medium agar plates containing the appropriate antibiotic selection. In the case of gene interruption with EZ-Tn5 ${ }^{\mathrm{TM}}<\mathrm{KAN}-2>$, use $50 \mu \mathrm{g} / \mathrm{mL}$ kanamycin for selection. In order to plate the full volume of the transformed $T$. denitrificans cells using fewer selection plates, the cells may be concentrated before plating. Centrifuge the $1-\mathrm{mL}$ cell suspension at $5000 \mathrm{rpm}$ for $5 \mathrm{~min}$. Gently resuspend cell pellet with $500 \mu \mathrm{L}$ Modified M9 Medium and spread $100 \mu \mathrm{L}$ of cell resuspension per plate.

12. Invert plates and incubate in an anaerobic chamber at $30^{\circ} \mathrm{C}$ for $7-10$ days, or until colonies start to appear. Allow colonies to grow to approximately $2 \mathrm{~mm}$ in diameter before transferring or before using for whole-cell PCR screening.

\section{$\underline{\text { 3.2.7 Confirmation of proper construction of insertion mutants }}$}


1. Use the same whole-cell PCR screening method as found in Section 3.2.3, with the following exceptions:

2. Use forward and reverse primers designed to anneal specifically to T. denitrificans genomic DNA sequence both upstream and downstream of the initial PCR product ( $T$. denitrificans gene of interest) generated in Section 3.2.2. The primers should generate an amplicon that contains a small portion of sequence upstream of the original gene of interest, the full sequence of the gene of interest, the EZ-Tn5 ${ }^{\mathrm{TM}}<\mathrm{KAN}-2>$ transposon within that sequence, and a small portion of sequence downstream of the original gene of interest (see Note 34). Due to the presence of the EZ-Tn5 ${ }^{\text {TM }}<$ KAN-2> transposon, a T. denitrificans insertion mutant should produce a PCR product that is approximately $1221 \mathrm{bp}$ greater than the PCR product formed when using wild-type $T$. denitrificans genomic DNA as template. See Fig. 2 as an example of primer locations and PCR amplicon sizes produced in a study (11) of $T$. denitrificans hynL (encodes large subunit of a periplasmic [NiFe]hydrogenase).

3. Controls utilizing different templates should be run. Suggestions include: (a) T. denitrificans wild-type DNA (e.g., see Fig. 2). This is a negative control or "no recombination event" control. The PCR product formed should be approximately $1221 \mathrm{bp}$ smaller than that of a knockout mutant; (b) No-template control (water). This is a negative control for any contaminating template in the PCR master mix or cross reactivity of the primers used; (c) pUC19:Td gene:kan plasmid as a positive control. pUC19 MCS primers will need to be used for this control. Depending on how many bp "outside" of the original T. denitrificans sequence the above (Step 2) primers anneal, this control should result in a product that is only a few hundred bp smaller than the PCR product from the T. denitrificans knockout. This is a good control to make sure that the PCR extension time and cycle number is set appropriately. 
4. Use annealing temperatures and extension times appropriate for the $T_{m}$ of the primers and for the expected amplicon size.

\subsection{Complementation of T. denitrificans insertion mutants}

A complementation vector, pTL2 (see Fig. 1), was successfully developed for $T$. denitrificans by Letain et al. (11). For complementation of a specific gene, the gene of interest must be PCR-amplified and inserted into pTL2 at the unique Hpal restriction site, as described in this section.

\section{$\underline{\text { 3.3.1 Construction of complementation vector with } T \text {. denitrificans gene of interest }}$}

A. PCR amplification of gene of interest

1. Prepare PCR master mix using a Phusion PCR kit (for creating blunt-end products) and use the following components for a $25-\mu \mathrm{L}$ PCR. Add the following components in the order listed into a 200- $\mu \mathrm{L}$ PCR reaction tube: (a) $15 \mu \mathrm{L}$ PCR-grade water, (b) $5 \mu \mathrm{L}$ 5X Phusion GC Buffer, (c) $0.5 \mu \mathrm{L} 10$ mM dNTPs, (d) $0.75 \mu \mathrm{L}$ DMSO, (e) $1.25 \mu \mathrm{L} 10 \mu \mathrm{M}$ Forward primer - phosphorylated; with start codon at the 5' end of primer, (f) $1.25 \mu \mathrm{L} 10 \mu \mathrm{M}$ Reverse primer - phosphorylated; including stop codon of coding sequence, (g) $1 \mu \mathrm{L} 1-50 \mathrm{ng} / \mu \mathrm{L} T$. denitrificans genomic DNA (mix tube contents before adding polymerase), (h) $0.25 \mu \mathrm{L}$ Phusion DNA polymerase (mix tube gently and centrifuge briefly to bring components to the bottom of the tube). Cap tube and place in thermal cycler.

2. Program thermal cycler for the following cycling parameters: (A) $98^{\circ} \mathrm{C}$ hold for $30 \mathrm{sec}$ (B) 35 cycles of the following - - (i) $98^{\circ} \mathrm{C}$ for $10 \mathrm{sec}$, (ii) $30 \mathrm{sec}$ at a temperature 3 to $5^{\circ} \mathrm{C}$ below the $T_{m}$ for primers (Note 7), (iii) $72^{\circ} \mathrm{C}$ for 1 min per $1 \mathrm{~kb}$ of expected PCR product (Note 8), (C) $72^{\circ} \mathrm{C}$ final extension (Note 8), (D) $4^{\circ} \mathrm{C}$ hold on completion.

3. Run $10 \mu \mathrm{L}$ of PCR on a $1.2 \%$ agarose gel with DNA molecular weight marker appropriate for expected size of PCR product.

4. See protocol 3.2.2, and follow steps 8-9. 
5. Optional: If future blunt-end ligation reactions appear inefficient, or if non-phosphorylated primers were used to create the PCR product, a DNA repair kit such as the End-It ${ }^{\text {TM }}$ DNA EndRepair Kit may be used to create 5'-phosphorylated, blunt-ended DNA.

B. Preparation of Hpal-digested pTL2 plasmid

1. Digest approximately 1-3 $\mu \mathrm{g}$ of $\mathrm{pTL} 2$ with Hpal restriction enzyme.

2. Prepare the Hpal digest reaction by adding the following components to a clean $1.7-\mathrm{mL}$ microfuge tube in the order listed: (a) nuclease-free water to $40 \mu \mathrm{L}$, (b) $4 \mu \mathrm{L} 10 \mathrm{X}$ Hpal restriction enzyme buffer (NEBuffer 4), (c) $1 \mu \mathrm{L} \mathrm{Hpal,} 5000$ units/mL, (d) 1-3 $\mu \mathrm{g}$ pTL2 DNA.

3. Mix gently and centrifuge briefly to bring contents to bottom of tube.

4. Incubate reaction at $37^{\circ} \mathrm{C}$ for 4 hours.

5. Add $1 \mu \mathrm{L} \mathrm{Hpal,} \mathrm{mix} \mathrm{gently,} \mathrm{and} \mathrm{digest} \mathrm{for} \mathrm{another} 4$ hours at $37^{\circ} \mathrm{C}$.

C. Dephosphorylation of Hpal-digested pTL2

Digested vector DNA does not need to be purified before treatment with Antarctic Phosphatase.

1. Prepare the dephosphorylation reaction by adding the following components to a clean 1.7-mL microfuge tube in the order listed: (a) $40 \mu \mathrm{L}$ pTL2 Hpal digest, (b) $4 \mu \mathrm{L}$ nuclease-free water, (c) 5 $\mu \mathrm{L}$ 10X Antarctic Phosphatase buffer, (d) $1 \mu \mathrm{L}$ Antarctic Phosphatase.

2. Mix gently and centrifuge briefly to bring contents to the bottom of the tube.

3. Incubate reaction at $37^{\circ} \mathrm{C}$ for 1.5 hours.

4. Heat-denature reaction at $65^{\circ} \mathrm{C}$ for $10 \mathrm{~min}$.

D. Gel purification of Hpal-digested and dephosphorylated pTL2

1. Prepare a $1.2 \%$ agarose preparative gel for purifying $\mathrm{Hpal}$ digested and dephosphorylated pTL2. (Notes 10-12)

2. Run the full volume of the digested/dephosphorylated pTL2 vector along with an appropriately sized DNA molecular weight marker. 
3. Cut out the approximate $6.2-\mathrm{kb}$ band and purify the vector DNA using a spin-column gel purification kit. (Note 35)

4. Elute the DNA in $50 \mu \mathrm{L}$ of elution buffer provided in the gel purification kit. (Note 36)

5. Run $2-3 \mu \mathrm{L}$ of the eluted DNA on a $1.2 \%$ agarose gel to check the size, for the presence of one band (representing the presence of digested plasmid DNA only), and concentration of pTL2. Run the gel with a DNA molecular weight marker that also gives approximate mass amounts. This is useful in determining the concentration of pTL2 DNA for future ligation reactions.

Concentration may also be determined by using $A_{260}$ measurements on a UV spectrophotometer, or an appropriate fluorimetric method.

E. Ligation of pTL2 with blunt-ended, purified PCR product ( $T$. denitrificans gene of interest) and transformation of ligated pTL2

1. Prepare the ligation reaction by adding the following components to a clean $1.7-\mathrm{mL}$ microfuge tube in the order listed: (a) nuclease-free water to $20 \mu \mathrm{L}$, (b) $2 \mu \mathrm{L}$ 10X T4 DNA Ligase Buffer, (c) 30-120 ng Hpal-digested, dephosphorylated, and purified pTL2, (d) T. denitrificans purified, blunt-ended PCR product created in Section 3.3.1 (A); add to a final molar amount 3 times the molar amount of pTL2 (Note 37, 16), (e) $1 \mu \mathrm{L}$ T4 DNA Ligase, 1 unit/ $\mu \mathrm{L}$.

2. Optional: Prepare control ligations. (Note 17)

3. Mix tube gently and centrifuge briefly to bring the contents to the bottom of the tube.

4. Incubate reaction at $16^{\circ} \mathrm{C}$ overnight or for at least 1 hour at room temperature.

5. Inactivate the T4 DNA Ligase by heating the reaction to $70^{\circ} \mathrm{C}$ for $10 \mathrm{~min}$.

6. Purify the ligation reaction using a spin-column nucleotide removal kit.

7. Elute the reaction in $30 \mu \mathrm{L}$ of elution buffer provided with the kit. 
8. Prepare for electroporation. Follow the One Shot ${ }^{\circledR}$ TOP $10^{\mathrm{TM}}$ E. coli transformation protocol described in Section 3.2.3 (D), with the following exceptions: (a) use $50 \mu \mathrm{g} / \mathrm{mL}$ gentamicin for selection instead of $100 \mu \mathrm{g} / \mathrm{mL}$ ampicillin, (b) X-gal is not necessary.

9. Use PCR to screen for the presence of the insert in pTL2 by using the following protocol (Note 38): (A) Prepare PCR master mix using the Advantage-GC 2 PCR kit and component volumes for a $25 \mu \mathrm{L}$ PCR. Multiply each of these by the number of clones that will be screened: (i) $1 \mu \mathrm{L} 10$ $\mu \mathrm{M}$ T. denitrificans forward primer (beginning of complementation gene), (ii) $1 \mu \mathrm{L} 10 \mu \mathrm{M}$ pUC19 forward primer, (iii) $0.5 \mu \mathrm{L}$ 50X dNTPs, (iv) $0.5 \mu \mathrm{L}$ 50X polymerase, (v) $5 \mu \mathrm{L} 5 \mathrm{X}$ GC2 Buffer, (vi) 2.5 $\mu \mathrm{L}$ 5M GC Melt, (vii) 14.5 $\mu \mathrm{L}$ PCR-grade water, (B) pipette $25 \mu \mathrm{L}$ of the PCR master mix into a 200- $\mu \mathrm{L}$ PCR tube. Do this for as many reactions as you will need.

10. Follow the same whole-cell PCR screening protocol as found in Section 3.2.3, with the following exception: use $50 \mu \mathrm{g} / \mathrm{mL}$ gentamicin for selection instead of $100 \mu \mathrm{g} / \mathrm{mL}$ ampicillin.

11. When thermal cycling is complete, analyze PCR reactions using gel electrophoresis.

12. The presence of a band the same size as the original PCR reaction for the complementation gene (steps 1-3 of Section 3.3.1 (A)) suggests the correct orientation of the T. denitrificans gene downstream of the kanamycin promoter. If no PCR product was generated, or the band is not the correct size, most likely the insert ligated into the vector in the incorrect orientation or there was no insert present.

13. When a clone has been determined to contain the pTL2 vector with the correct size and orientation of the complementation gene behind the kan promoter, use the newly plated cells to inoculate $5 \mathrm{~mL}$ of $\mathrm{LB}$ medium containing $50 \mu \mathrm{g} / \mathrm{mL}$ gentamicin. Incubate overnight at $37^{\circ} \mathrm{C}$ with 200-rpm shaking. (Note 39)

14. Transfer $5 \mathrm{~mL}$ of the overnight $E$. coli culture to a $15-\mathrm{mL}$ centrifuge tube and centrifuge for $5 \mathrm{~min}$ at $6800 \times$ g. Remove supernatant. (Note 23) 
15. Extract the pTL2 complementation vector using a spin-column plasmid miniprep kit.

16. Once the complementation vector has been isolated, determine the approximate concentration by gel electrophoresis with a DNA molecular weight and mass marker, $A_{260}$ reading, or an appropriate fluorimetric method. (Note 40)

17. After the complementation vector has been isolated, check the vector again for correct orientation and presence of the complementation gene. Use a few more PCR screens if possible. The following primer combinations are suggested: (a) pUC19 MCS forward primer and forward primer of the $T$. denitrificans complementation gene (orientation of complementation gene behind kan promoter), (b) pUC19 MCS reverse primer and reverse primer of the $T$. denitrificans complementation gene (confirmation of orientation of complementation gene behind kan promoter; expected amplicon size of forward primers together plus size of kan promoter), (c) pUC19 MCS forward primer and pUC19 MCS reverse primer (presence of complementation gene).

18. Due to the potential for incorrect bp incorporation by the DNA polymerase during amplification of the complementation gene insert, sequencing of the complementation gene within pTL2 is strongly suggested.

After the complementation vector has been determined to be correctly constructed, and the concentration of the DNA has been determined, transformation of the complementation vector into $T$. denitrificans may be performed. Follow the protocol for transformation into T. denitrificans as outlined in Section 3.2.5 and 3.2.6, with the following exceptions: (a) transform with $100-200$ ng of plasmid DNA (b) use $50 \mu \mathrm{g} / \mathrm{mL}$ gentamicin for selection. Kanamycin at $50 \mu \mathrm{g} / \mathrm{mL}$ may also be included for continued selection of the $T$. denitrificans knockout mutant with the EZ-Tn5 ${ }^{\mathrm{TM}}<\mathrm{KAN}-2>$ transposon inserted. 


\subsubsection{Confirmation of genotype of complemented mutants: isolation of complementation}

\section{$\underline{\text { vector }}$}

1. After T. denitrificans colonies have grown on selection plates to a size of approximately $2 \mathrm{~mm}$ in diameter, pick isolated colonies and resuspend in $400 \mu \mathrm{L}$ of Anaerobic Td Medium supplemented with gentamicin at $50 \mu \mathrm{g} / \mathrm{mL}$. Keep cultures growing in anaerobic chamber at $30^{\circ} \mathrm{C}$. After noticeable growth occurs in the culture, usually after 2 days, transfer the culture to $4 \mathrm{~mL}$ of Anaerobic Td Medium supplemented with gentamicin at $50 \mu \mathrm{g} / \mathrm{mL}$. After 2 days, transfer the $4 \mathrm{~mL}$ culture to $40 \mathrm{~mL}$ of Anaerobic Td Medium supplemented with gentamicin at $50 \mu \mathrm{g} / \mathrm{mL}$. Incubate $40 \mathrm{~mL}$ culture for 2 days. The culture should reach an $\mathrm{OD}_{600}$ of 0.1 to 0.25 .

2. Transfer $40 \mathrm{~mL}$ of culture to a $50-\mathrm{mL}$ centrifuge tube, and spin cells at $3220 \times \mathrm{g}$ for $10 \mathrm{~min}$.

3. Decant supernatant and resuspend cells in $20 \mathrm{~mL} 10 \mathrm{mM}$ Tris buffer, $\mathrm{pH}$ 8.0.

4. Spin cells at $3220 \times g$ for $10 \mathrm{~min}$.

5. Decant supernatant and resuspend cells in $20 \mathrm{~mL} 10 \mathrm{mM}$ Tris buffer, $\mathrm{pH}$ 8.0.

6. Spin cells at $3220 \times g$ for $10 \mathrm{~min}$.

7. Decant supernatant and resuspend cells in $1 \mathrm{~mL} 10 \mathrm{mM}$ Tris buffer, $\mathrm{pH} 8.0$.

8. Isolate the complementation plasmid from $T$. denitrificans cells using a spin-column plasmid miniprep kit. Run $5 \mu \mathrm{L}$ of the plasmid prep on a 1.2\% agarose gel with an appropriately sized DNA molecular weight marker. (The size of the complementation vector pTL2 without an insert is $6.2 \mathrm{~kb}$.)

9. If the appropriate size band is present, some of the plasmid prep may also be digested with a single-site restriction enzyme, in order to better determine the size and concentration of the complementation vector. Ndel and Stul are examples of single-site restriction enzymes for pTL2, but the $T$. denitrificans gene inserted into the Hpal site will need to be checked for existing restriction sites. 


\subsubsection{Confirmation of genotype of complemented mutants: PCR analysis}

The primer and template combinations described below can be used to confirm the presence of the complementation vector in the transformed $T$. denitrificans cells and to confirm the continued presence of the EZ-Tn $5^{\mathrm{TM}}<\mathrm{KAN}-2>$ transposon in the genome of the $T$. denitrificans knockout mutant. (for example, see Fig. 2)

1. PCR confirmation of knockout mutation: (A) Perform PCR using the same primers as used in Section 3.2.7 to confirm presence of the insertion mutation (this primer combination should be specific for the genomic DNA of the knockout mutant, and should not create any product due to the presence of the complementation plasmid). Use gDNA extracted from the complemented $T$. denitrificans insertion mutant as template (see Note 3); (B) A negative control PCR may be run using this primer combination and the original complementation vector (with $T$. denitrificans gene insert) plasmid prep as a template. Do not use the plasmid prep isolated from the $T$. denitrificans complement as template, as the plasmid prep will very likely contain contaminating T. denitrificans gDNA; (C) A positive control PCR may be run using the non-complemented $T$. denitrificans insertion mutant gDNA as template; (D) A control PCR may be run using wild-type T. denitrificans gDNA as template (e.g., see Fig. 2). This should give a smaller amplicon size than the amplicon generated using gDNA from the $T$. denitrificans knockout.

2. This PCR is to confirm the presence of the wild-type gene of interest in the plasmid DNA of the complemented strain. Use the same $T$. denitrificans reverse primer used to create the insert for the complementation vector (Section 3.3.1 (A), steps 1-2) in conjunction with the pUC19 MCS reverse primer (see Note 38). Use the plasmid DNA isolated from the complemented $T$. denitrificans insertion mutant as template for the PCR (e.g., see Fig. 2). (A) The pUC19 MCS reverse primer should be specific for the complementation vector, and the resulting product should be due to the presence of the complementation vector and not due to $T$. denitrificans 
gDNA; (B) A negative control PCR may be run using gDNA from the non-complemented $T$. denitrificans insertion mutant. Do not use gDNA isolated from the complemented mutant, as the gDNA prep will very likely contain contaminating plasmid DNA; (C) A positive control PCR may be run using as a template the same complementation plasmid prep transformed into the T. denitrificans mutant.

3. Prepare PCR master mix using the Advantage-2 GC PCR kit and the following components for a 25- $\mu \mathrm{L}$ PCR. Multiply each of these by the number of samples and controls that will be tested, and mix the following components in a clean 1.7- $\mathrm{mL}$ microfuge tube in the order listed: (a) 13.5 $\mu \mathrm{L}$ PCR-grade water, (b) $5 \mu \mathrm{L}$ 5X GC2 Buffer, (c) $2.5 \mu \mathrm{L}$ 5M GC Melt, (d) $1 \mu \mathrm{L} 10 \mu \mathrm{M}$ forward primer, (e) $1 \mu \mathrm{L} 10 \mu \mathrm{M}$ reverse primer, (f) $0.5 \mu \mathrm{L}$ 50X dNTPs, (g) $1 \mu \mathrm{L}$ DNA template (1-10 ng) (mix tube contents before adding polymerase), (h) $0.5 \mu \mathrm{L} 50 \mathrm{X}$ polymerase (mix tube gently and centrifuge briefly to bring the components to the bottom of the tube).

4. Thermal cycle using annealing temperatures appropriate for the $T_{m}$ of the primers in the reaction and extension times appropriate for expected amplicon size.

5. Check for expected PCR product size by gel electrophoresis to confirm presence of insertion mutation and complementation vector. 


\section{Notes}

Note 1: Because CTAB can be difficult to dissolve into solution, heating the solution while dissolving the CTAB is helpful. Begin by first dissolving $4.1 \mathrm{~g} \mathrm{NaCl}$ in $80 \mathrm{~mL}$ water in a $250-\mathrm{mL}$ glass container with stir bar, on a stirring hot plate. Slowly apply heat (to approximately $65^{\circ} \mathrm{C}$ ) while slowly adding $10 \mathrm{~g} \mathrm{CTAB}$. (Add 1-2 g CTAB at a time, wait for it to dissolve, and continue adding 1-2 $\mathrm{g}$ at a time until $10 \mathrm{~g}$ of CTAB has been added). This process can take 2-3 hours. After CTAB is fully in solution, adjust final volume to $100 \mathrm{~mL}$, allow solution to cool, and sterilize by autoclaving or filter sterilizing.

Note 2: Use ultrapure water (18-M $\Omega$ resistance) obtained from a Milli-Q Biocel system (Millipore, Bedford, MA) or similar purification system for creating all solutions in this chapter unless otherwise noted (such as PCR-grade water or nuclease-free water).

Note 3: When it is not essential to have high-quality gDNA extracted from $T$. denitrificans (as is the case when doing PCR screening of mutants or clones), a genomic DNA extraction kit that utilizes either spincolumn purification or ethanol precipitation may be used to extract gDNA from $T$. denitrificans cells.

Note 4: Using Kpnl as a restriction enzyme worked well for our purposes. Any restriction enzyme that has a restriction site in the pUC19 multiple cloning site (MCS) may be considered for use. The $T$. denitrificans genomic sequence chosen for insertion mutation must be screened for, and should not contain, a restriction site for the restriction enzyme chosen. Be sure that it is a single-site cutter within the MCS of pUC19 only.

Note 5: Primers may also be designed with phosphorylated ends for blunt cloning into the Smal site of pUC19.

Note 6: Consider designing a set of primers close to the start and stop codons of the $T$. denitrificans gene of interest. These primers will be used in PCR screening for the insertion of the EZ-Tn5 ${ }^{\mathrm{TM}}<\mathrm{KAN}-2>$ transposon into the $T$. denitrificans gene. The size of the smaller amplicon generated by these primers is more closely determined when sizing by gel electrophoresis methods. 
Note 7: Using a thermal cycler with temperature gradient capability is useful for optimizing the annealing temperature needed to get the greatest amount of desired product with high purity.

Note 8: When choosing PCR extension times, a good rule of thumb is to allow 1 min of extension at $72^{\circ} \mathrm{C}$ per $1 \mathrm{~kb}$ of product expected. We found we needed $30-45 \mathrm{sec}$ more per cycle. That is, when expecting a $4-\mathrm{kb}$ product, a $72^{\circ} \mathrm{C}$ extension time of $4 \mathrm{~min}, 45 \mathrm{sec}$ per cycle was used. For final $72^{\circ} \mathrm{C}$ extension, we allowed 2 min per kb expected amplicon size (for example, for expected 2 kb product, a final $72^{\circ} \mathrm{C}$ extension of 4 min was used).

Note 9: DNA ladders that also include mass amounts are convenient to use, as they allow for approximating DNA amounts needed for digests, ligations, and transposition reactions (for example Bionexus Hi-Lo Mass Ladder).

Note 10: If multiple bands were present in the gel when the original reaction was analyzed, then the correct sized band may be isolated from the other products by running the pooled reactions on a $1.2 \%$ agarose gel and isolating via gel extraction. To run a large volume of sample on an agarose gel, a preparative comb should be used. If a preparative comb cannot be obtained, then a large well may be created by wrapping lab tape around four to five teeth of a regular sized comb to create one large tooth (or well). Alternatively, the PCR reactions can be pooled together and concentrated using a spin-column DNA purification kit. Elute in a volume that can fit in the wells created by a standard gel comb.

Note 11: To be conservative when choosing an elution volume, assume $20 \%$ DNA loss during the purification procedure.

Note 12: There are spin-column kits available that are specifically designed for purifying and eluting DNA in small volumes $(<30 \mu \mathrm{L})$ if necessary (e.g., Qiagen's MinElute PCR Purification Kit or similar).

Note 13: Take care to remove the band that is digested pUC19, and not a band that contains undigested pUC19. If necessary, run 2-5 $\mu \mathrm{L}$ of the digested/dephosphorylated pUC19 reaction with an uncut pUC19 
control on a gel to check for complete digestion, and to be able to distinguish between bands resembling digested versus undigested pUC19.

Note 14: The volume chosen for elution should be dependent on how much pUC19 was digested and dephosphorylated. Assume approximately 80\% DNA recovery efficiency from the purification procedure. Concentrate the digested pUC19 DNA to $20-100 \mathrm{ng} / \mu \mathrm{L}$.

Note 15: For ligation of DNA with cohesive ends, the following insert to vector ratios and molar amounts are suggested:

\section{3:1 insert-to-vector ratio \\ Vector DNA at 3-30 fmol \\ Insert DNA at 9-90 fmol}

Note 16: Calculation of molar ratios (for vector DNA and double-stranded DNA ends of insert DNA):

$\mu \mathrm{g}$ DNA $=$ fmol DNA $\times 1 \mu \mathrm{g} / 3000 \mathrm{fmol} \times$ DNA length (bp)/1000 bp

[Based on Invitrogen Technical Bulletin 15244-2]

Note 17: Optional controls for ligation and transformation:

Supercoiled vector or control DNA provided with competent cells. This control tests for transformation efficiency of competent cells and ensures correct electroporation settings. Refer to instructions provided by competent cell provider for expected number of colonies that should result from high-efficiency transformation.

\section{Restriction endonuclease-digested vector, dephosphorylated, no ligase present in ligation}

reaction. Use the same amount of digested vector in this "no-ligase" control ligation reaction as is used in the experimental ligation reactions. Transform the same amount as in the experimental ligation reaction. Very few to no colonies should result from this transformation. This control tests for the presence of undigested vector in the ligation reaction. 
No DNA present. Transform the same volume of water or Tris buffer as volume of ligation reaction. No colonies should result from this transformation. This control tests for the purity of the competent cells used and the potency of the antibiotic present in the selection plates.

Note 18: If using an electroporator other than the one listed in Section 2.2, follow manufacturer's recommendations for transformation of $E$. coli.

Note 19: If arcing occurs during the electroporation, assume transformation efficiency will be poor and repeat the electroporation of the ligation reaction with a new cell aliquot. If arcing continues, smaller volumes of the ligation reaction may need to be used, or the ligation reaction may need to be repurified; the presence of salt with DNA may cause arcing.

Note 20: Depending on the efficiency of the ligation and subsequent transformation, dilutions of the electroporated cells may need to be made before plating to ensure the presence of isolated colonies. Note 21: Placing the plates at $4^{\circ} \mathrm{C}$ for several hours can enhance the blue color and may make the blue colonies easier to distinguish from the white colonies.

Note 22: It is a good practice to pick more than one clone containing pUC19 and the appropriate insert, in case there is a problem with a clone during subsequent techniques or sequencing.

Note 23: It is good practice to create a freezer stock of the clones chosen. Mix $500 \mu \mathrm{L}$ of the overnight culture with $500 \mu \mathrm{L}$ of $80 \%$ sterile glycerol, mix thoroughly, and store at $-80^{\circ} \mathrm{C}$.

Note 24: If using gel electrophoresis to determine concentration, cutting a small portion of the plasmid prep with a single-site cutter may be necessary. The restriction enzyme Smal is a single-site cutter for pUC19, and may be used, but the T. denitrificans insert sequence must be checked for the presence of Smal restriction sites. Cutting the pUC19:T. denitrificans insert plasmid will allow a better approximation of concentration, as the vector can be present in a supercoiled, linear, or nicked state, which may result in the presence of three different-sized bands. 
Note 25: The presence of the desired insert in pUC19 can be checked further at this point. Digesting the pUC19:T. denitrificans insert plasmid with Kpnl should cut the insert from the MCS of pUC19, and two bands should be present on an agarose gel. The bands present should be the approximate size of (1) pUC19 (2686 bp) and (2) the T. denitrificans PCR product that was created in protocol 3.2.2.

Note 26: For determining the molar equivalents of pUC19:T. denitrificans insert plasmid and the EZTn5 ${ }^{\mathrm{TM}}<\mathrm{KAN}-2>$ transposon, use the following equation:

$\mu \mathrm{mol}$ target DNA $=\mu \mathrm{g}$ target DNA/[(\# base pairs in target DNA) $\times 660 \mu \mathrm{g} b / \mu \mathrm{mol} b p(\mathrm{MW})]$ Where "target DNA" represents pUC19 including $T$. denitrificans insert.

Note 27: Depending on the efficiency of the transposition and subsequent transformation, dilutions of the electroporated cells may need to be made before plating to ensure the presence of isolated colonies. (A ten-fold dilution of the cells is a good starting point, however the appropriate dilution will need to be determined for each experiment.)

Note 28: PCR screening with the T. denitrificans forward primer and either the EZ-Tn5 ${ }^{\mathrm{TM}} \mathrm{KAN}-2$ forward or reverse primer checks for the potential insertion of the EZ-Tn5 $5^{\mathrm{TM}}<\mathrm{KAN}-2>$ transposon in either direction within the $T$. denitrificans gene.

Note 29: To better ensure that the gene interruption prevents translation of a functional protein, the transposon should insert within 100 - 500 bp downstream of the ATG site of the $T$. denitrificans gene of interest. When screening for placement of the transposon within the $T$. denitrificans gene, it is convenient to use a primer located within a few hundred base pairs upstream of the ATG translation start site, as opposed to the original primer, which lies $1000-1500$ bp upstream. It tends to be easier to determine the size of a smaller $(100-700-b p)$ size product on an agarose gel than one greater than 1 kb.

Note 30: The sequences resulting from each $\mathrm{EZ}-\mathrm{Tn} 5^{\mathrm{TM}}$ sequencing reaction should result in $T$. denitrificans base-pair reads that combine to form the complete and uninterrupted $T$. denitrificans 
sequence of the gene of interest. The 19-base mosaic-end sequence may be present in the sequence reads and can be used to distinguish transposon from target gene sequence. At the site of transposition, there will also be a 9-bp direct duplication of the target gene sequence. Refer to the EZ$\mathrm{Tn}^{\mathrm{TM}}<\mathrm{KAN}-2>$ Insertion Kit Manual for more information.

Note 31: T. denitrificans electrocompetent cells should be prepared immediately before use, as the efficiency of stored or frozen electrocompetent $T$. denitrificans cells has never been tested.

Note 32: If $T$. denitrificans electrocompetent cells will be prepared often in the lab, it is convenient to keep a bottle of sterile ultrapure water stored at $4^{\circ} \mathrm{C}$.

Note 33: Make a note of the pulse time. Ideally, the pulse time will be approx. 4-5 ms. If the sample arcs, the transformation efficiency may be markedly decreased. Cells may still be plated, but the electroporation should be repeated with 2-5 $\mu \mathrm{L}$ DNA in another batch of cells in another cuvette. If arcing occurs again, decrease volume of DNA being transformed, or the DNA sample may need to be repurified; the presence of salt with DNA may cause arcing.

Note 34: Choosing primers that anneal to sequence outside of the original $T$. denitrificans PCR product will confirm that the homologous recombination occurred at the intended site within the $T$. denitrificans genome.

Note 35: Take care to cut the band that is digested pTL2, and not any vector DNA that may not have been cut during the Hpal digestion reaction. If necessary, run a smaller amount of the digested/dephosphorylated pTL2 reaction with an uncut pTL2 control on a previous gel to check for complete digestion, and to be able to distinguish between a band resembling Hpal-digested and nonHpal-digested pTL2.

Note 36: The volume chosen for elution should depend on how much pTL2 was digested and dephosphorylated. Assume approximately $80 \%$ DNA recovery efficiency from the spin-column gel purification. Try to concentrate pTL2 DNA to at least $100 \mathrm{ng} / \mu \mathrm{L}$. 
Note 37: For blunt-end ligations, the following insert-to-vector ratios and molar amounts are suggested:

$$
\begin{aligned}
& \text { 3:1 insert-to-vector ratio } \\
& \text { Vector DNA at } 15-60 \mathrm{fmol} \\
& \text { Insert DNA at } 45-180 \mathrm{fmol}
\end{aligned}
$$

Note 38: Within PTL2, the kanamycin promoter is upstream of the MCS in the orientation HindIII-toKpnl. The MCS of pTL2 was derived from the MCS of pUC19 and therefore the pUC19 MCS primers used in Section 3.2.3 can also be used for screening in pTL2. The use of the forward pUC19 MCS primer, along with the forward primer specific for the $T$. denitrificans gene, will screen for the proper orientation of the complementation gene in relation to the kanamycin promoter within the complementation vector (see Fig. 1).

Note 39: It is good practice to pick more than one clone containing pTL2 and the appropriate insert, in case there is a problem with the chosen clone during subsequent techniques or sequencing.

Note 40: If using gel electrophoresis to determine concentration, cutting a small portion of the plasmid prep with a single-site cutter may be needed. A digest performed with Ndel should cut the complementation vector once, but the cloned insert must be checked for Ndel restriction sites. Cutting the vector will allow a better approximation of concentration, as an uncut vector can potentially run as different sizes (supercoiled, linear, nicked), which can lead to difficulty in determining the actual concentration of the plasmid. 


\section{References}

1. Beller, H. R., Chain, P. S., Letain, T. E., Chakicherla, A., Larimer, F. W., Richardson, P. M., Coleman, M. A., Wood, A. P., and Kelly, D. P. (2006) The genome sequence of the obligately chemolithoautotrophic, facultatively anaerobic bacterium Thiobacillus denitrificans. J. Bacteriol. $188,1473-1488$.

2. Nemati, M., Jenneman, G. E., and Voordouw, G. (2001) Impact of nitrate-mediated microbial control of souring in oil reservoirs on the extent of corrosion. Biotechnol. Prog. 17, 852-859.

3. Beller, H. R., Madrid, V., Hudson, G. B., McNab, W. W., and Carlsen, T. (2004) Biogeochemistry and natural attenuation of nitrate in groundwater at an explosives test facility. Appl. Geochem. $19,1483-1494$.

4. Pauwels, H., Kloppmann, W., Foucher, J.-C., Martelat, A., and Fritsche, V. (1998) Field tracer test for denitrification in a pyrite-bearing schist aquifer. Appl. Geochem. 13, 767-778.

5. Straub, K. L., Benz, M., Schink, B., and Widdel, F. (1996) Anaerobic, nitrate-dependent microbial oxidation of ferrous iron. Appl. Environ. Microbiol. 62, 1458-1460.

6. Sierra-Alvarez, R., Beristain-Cardoso, R., Salazar, M., Gomez, J., Razo-Flores, E., and Field, J. A. (2007) Chemolithotrophic denitrification with elemental sulfur for groundwater treatment. Water Res. 41, 1253-1262.

7. Zhao, Z., Qiu, W., Koenig, A., Fan, X., and Gu, J. D. (2004) Nitrate removal from saline water using autotrophic denitrification by the bacterium Thiobacillus denitrificans MP-1. Environ. Technol. 25, 1201-1210. 
8. Beller, H. R. (2005) Anaerobic, nitrate-dependent oxidation of U(IV) oxide minerals by the chemolithoautotrophic bacterium Thiobacillus denitrificans. Appl. Environ. Microbiol. 71, 21702174.

9. Wu, W. M., Carley, J., Green, S. J., Luo, J., Kelly, S. D., Van Nostrand, J., Lowe, K., Mehlhorn, T., Carroll, S., Boonchayanant, B., Lofller, F. E., Watson, D., Kemner, K. M., Zhou, J., Kitanidis, P. K., Kostka, J. E., Jardine, P. M., and Criddle, C. S. (2010) Effects of nitrate on the stability of uranium in a bioreduced region of the subsurface. Environ. Sci. Technol. 44, 5104-5111.

10. Beller, H. R., Letain, T. E., Chakicherla, A., Kane, S. R., Legler, T. C., and Coleman, M. A. (2006) Whole-genome transcriptional analysis of chemolithoautotrophic thiosulfate oxidation by Thiobacillus denitrificans under aerobic versus denitrifying conditions. J. Bacteriol. 188, 70057015.

11. Letain, T. E., Kane, S. R., Legler, T. C., Salazar, E. P., Agron, P. G., and Beller, H. R. (2007) Development of a genetic system for the chemolithoautotrophic bacterium Thiobacillus denitrificans. Appl. Environ. Microbiol. 73, 3265-3271.

12. Beller, H. R., Legler, T. C., Bourguet, F., Letain, T. E., Kane, S. R., and Coleman, M. A. (2009) Identification of c-type cytochromes involved in anaerobic, bacterial U(IV) oxidation. Biodegradation 20, 45-53.

13. Kulpa, C. F., Roskey, M. T., and Travis, M. T. (1983) Transfer of plasmid RP1 into chemolithotrophic Thiobacillus neapolitanus. J. Bacteriol. 156, 434-436.

14. Baker, S. H., Jin, S., Aldrich, H. C., Howard, G. T., and Shively, J. M. (1998) Insertion mutation of the form I cbbl gene encoding ribulose bisphosphate carboxylase/oxygenase (RuBisCO) in Thiobacillus neapolitanus results in expression of form II RuBisCO, loss of carboxysomes, and an increased $\mathrm{CO}_{2}$ requirement for growth. J. Bacteriol. 180, 4133-4139. 
15. Peng, J. B., Yan, W. M., and Bao, X. Z. (1994) Plasmid and transposon transfer to Thiobacillus ferrooxidans. J. Bacteriol. 176, 2892-2897.

16. Liu, Z., Guiliani, N., Appia-Ayme, C., Borne, F., Ratouchniak, J., and Bonnefoy, V. (2000) Construction and characterization of a recA mutant of Thiobacillus ferrooxidans by marker exchange mutagenesis. J. Bacteriol. 182, 2269-2276.

17. van Zyl, L. J., van Munster, J. M., and Rawlings, D. E. (2008) Construction of arsB and tetH mutants of the sulfur-oxidizing bacterium Acidithiobacillus caldus by marker exchange. Appl. Environ. Microbiol. 74, 5686-5694.

18. Yanisch-Perron, C., Vieira, J., and Messing, J. (1985) Improved M13 phage cloning vectors and host strains: nucleotide sequences of the M13mp18 and pUC19 vectors. Gene 33, 103-119.

19. Widdel, F. and Bak, F. (1992) Gram-negative mesophilic sulfate-reducing bacteria. In The prokaryotes (Balows, A., Trüper, H. G., Dworkin, M., Harder, W., and Schleifer, K.-H., eds.), pp. 3352-3378. Springer-Verlag, New York, N.Y.

20. Feil, W. S., Feil, H. , and Copeland, A. (2004) Bacterial genomic DNA isolation using CTAB. Joint Genome Institute. http://my.jgi.doe.gov/general/ Accessed 1 September 2010. 


\section{Acknowledgments}

For HRB, work conducted by the Joint BioEnergy Institute was supported by the Office of Science, Office of Biological and Environmental Research, of the U. S. Department of Energy under Contract No. DEAC02-05CH11231. Regarding work conducted at Lawrence Livermore National Laboratory, LLNL is operated by Lawrence Livermore National Security, LLC, for the U.S. Department of Energy, National Nuclear Security Administration under Contract DE-AC52-07NA27344. 
TABLE 1. Strains, plasmids, and transposons required

\begin{tabular}{|c|c|c|}
\hline Strain, plasmid, or transposon & Genotype or markers; characteristics and uses & $\begin{array}{l}\text { Source or } \\
\text { reference }\end{array}$ \\
\hline \multicolumn{3}{|l|}{ Strains } \\
\hline Escherichia coli TOP10 & $\begin{array}{l}\mathrm{F}^{-} \text {mcrA } \Delta(\text { mrr-hsdRMS-mcrBC) } \phi 80 / a c Z \Delta M 15 \\
\Delta \text { lacX74 recA1 araD139 } \Delta(\text { ara-leu }) 7967 \text { galU galK } \\
\text { rpsL }\left(\mathrm{str}^{\mathrm{R}}\right) \text { endA1 nupG }\end{array}$ & Invitrogen \\
\hline \multicolumn{3}{|l|}{ Thiobacillus denitrificans } \\
\hline ATCC 25259 & Wild type & ATCC \\
\hline \multicolumn{3}{|l|}{ Plasmids } \\
\hline pUC19 & $\mathrm{pMB1}, \mathrm{amp}^{\mathrm{R}}$; cloning vector & (18) \\
\hline pTL2 & $\begin{array}{l}\text { IncP, gent }{ }^{\mathrm{R}}, \mathrm{amp}^{\mathrm{S}}, \mathrm{pTL1} \text { with bla::gent; } T \text {. } \\
\text { denitrificans expression vector }\end{array}$ & (11) \\
\hline \multicolumn{3}{|l|}{ Transposons } \\
\hline Tn-kan & $\begin{array}{l}\operatorname{kan}^{\mathrm{R}}, \mathrm{EZ}-\mathrm{Tn} 5<\mathrm{KAN}-2>\text { DNA fragment with } \\
\text { kanamycin resistance selection marker located } \\
\text { between Mosaic End (ME) Tn5 transposase } \\
\text { recognition sequences }\end{array}$ & EpiCentre \\
\hline
\end{tabular}




\section{Figure Legends}

Figure 1. Schematic diagram of the complementation vector (pTL2) used in T. denitrificans. The following features are shown: oriV, the RK2 minimal vegetative origin of replication; oriT, the origin of transfer; $\operatorname{trf} A$, encodes the RK2 replication initiation protein; bla, the beta-lactamase gene encoding ampicillin resistance; $\mathrm{P}_{\mathrm{Kan}}$, the 110-bp promoter of the kanamycin resistance gene from pTnMod-OKm'; and relevant restriction sites. The Hpal restriction site is unique and allows placement of genes for complementation. Kpnl and HindIII bracket the original multiple cloning site (MCS) from pRR10. Reproduced with permission from the American Society for Microbiology (Applied and Environmental Microbiology, 2007 73:3265-3271).

Figure 2. Example of confirming (i) proper construction of insertion mutants and (ii) the genotype of complemented mutants (Section 3.2.7 and Sections 3.3.2 - 3.3.3, respectively). A target in this study (11) was the hynL gene, which encodes the large subunit of a periplasmic [NiFe]hydrogenase). (A) Electropherogram of PCR products from wild-type T. denitrificans, the hynL mutant, and the complemented hynL mutant as well as digested plasmid DNA from the complemented mutant. Lane 1, HyperLadder III, Bioline (Taunton, MA); Lane 2, wild-type DNA, primers hynL-2-f,r; Lane 3, hynL mutant (strain TL001) DNA, primers hynL-2-f,r; Lane 4, complemented mutant - genomic DNA, primers hynL-2f,r; Lane 5, complemented mutant - plasmid DNA, primers hynL-2-r and pUC19-r; Lane 6, Hi-Lo Marker, Bionexus (the arrow indicates $8 \mathrm{~kb}$ ); Lane 7, complemented mutant - pTL3 plasmid DNA, Ndel digested. (B) Map of primer position and amplicon size corresponding to Lanes 2 to 5 in panel A. Note that the hynL-2-f primer anneals with genomic DNA upstream of the hynL gene, whereas the pUC19-r primer anneals with pTL3 plasmid DNA, rendering these primers specific to the $T$. denitrificans genome and the complementation plasmid pTL3, respectively. Reproduced with permission from the American Society for Microbiology (Applied and Environmental Microbiology, 2007 73:3265-3271). 
EcoRI

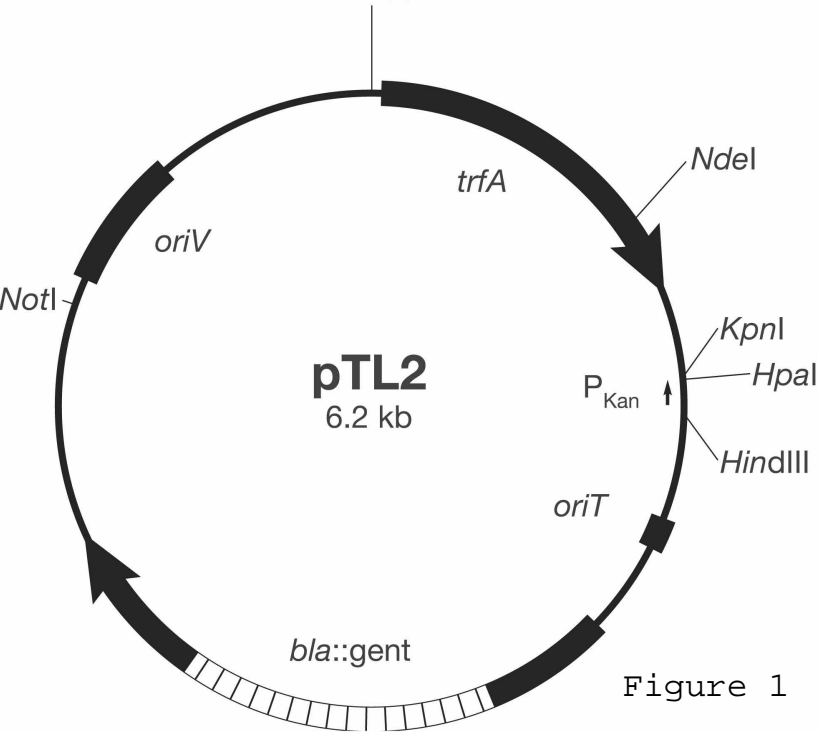


hynL Compl. mutant

WT mutant genomic plasmid
Compl. mutant pTL3

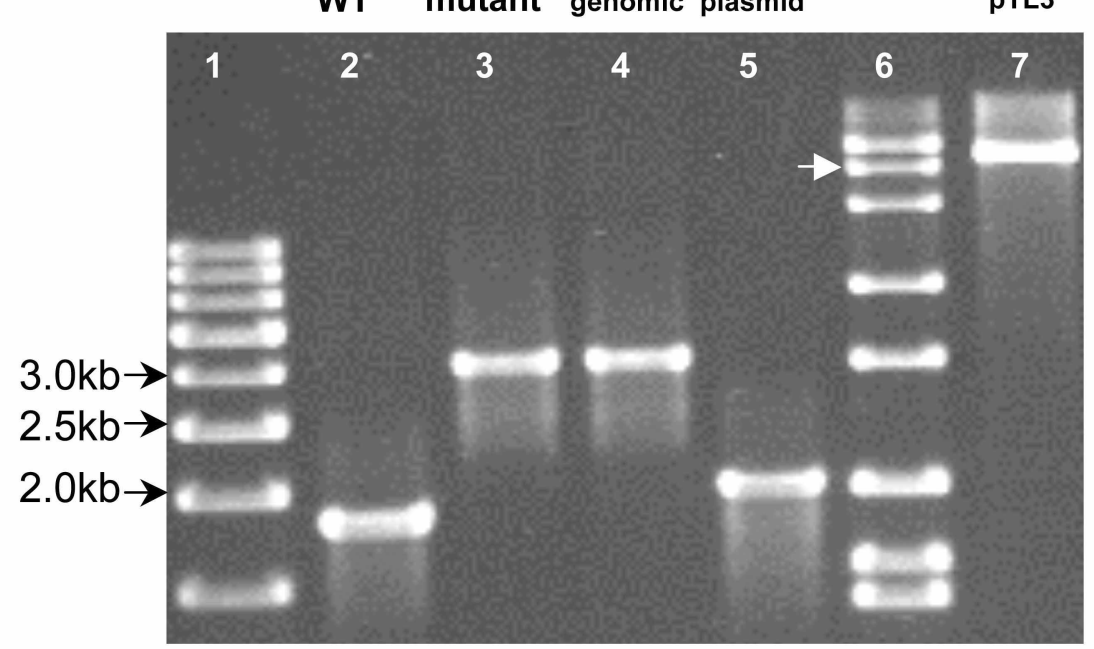

B

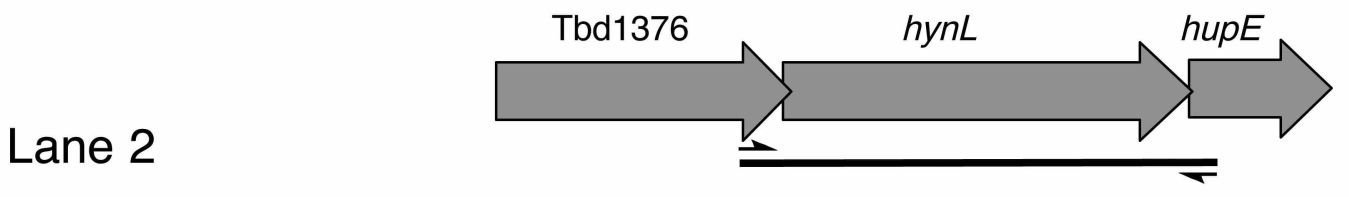

$1.9 \mathrm{~kb}$

Lanes 3 and 4

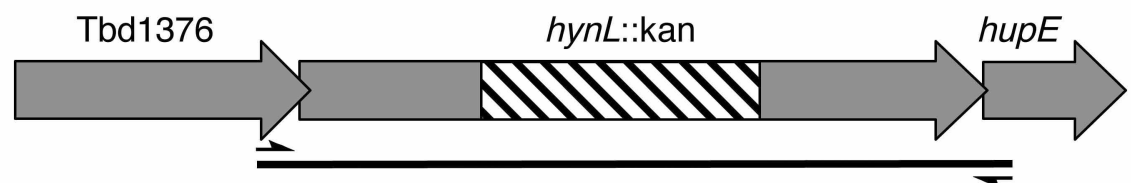

$3.1 \mathrm{~kb}$

Lane 5

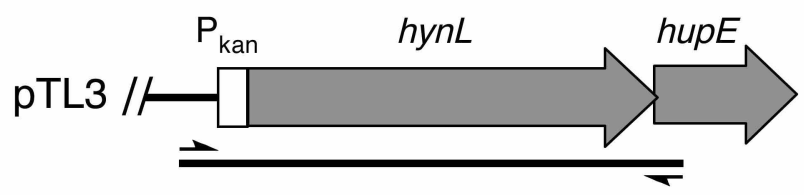

$2.0 \mathrm{~kb}$ 


\section{DISCLAIMER}

This document was prepared as an account of work sponsored by the United States Government. While this document is believed to contain correct information, neither the United States Government nor any agency thereof, nor The Regents of the University of California, nor any of their employees, makes any warranty, express or implied, or assumes any legal responsibility for the accuracy, completeness, or usefulness of any information, apparatus, product, or process disclosed, or represents that its use would not infringe privately owned rights. Reference herein to any specific commercial product, process, or service by its trade name, trademark, manufacturer, or otherwise, does not necessarily constitute or imply its endorsement, recommendation, or favoring by the United States Government or any agency thereof, or The Regents of the University of California. The views and opinions of authors expressed herein do not necessarily state or reflect those of the United States Government or any agency thereof or The Regents of the University of California.

Ernest Orlando Lawrence Berkeley National Laboratory is an equal opportunity employer. 